Maden, S. ve Önal, A. (2020). Türkçe ve İngilizce ders kitapları üzerine karşılaştırmalı bir analiz: 7. sınıf örneği. Ana Dili Eğitimi Dergisi, 8(3), 732-752.

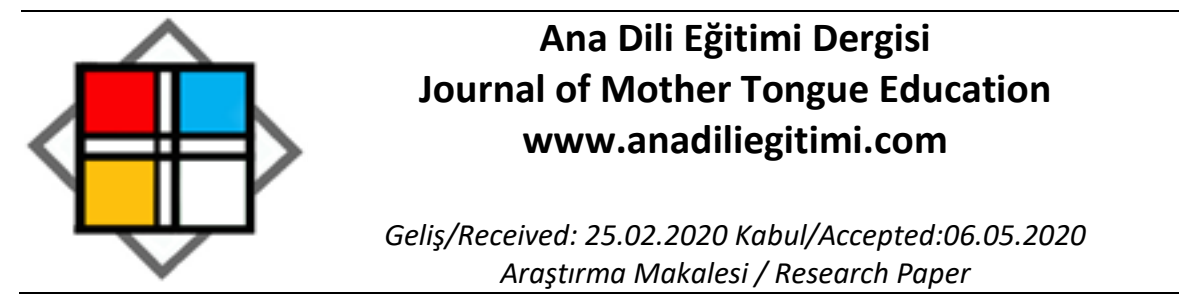

\title{
Türkçe ve İngilizce Ders Kitapları Üzerine Karşılaştırmalı Bir Analiz: 7. Sınıf Örneği
}

\author{
Sedat MADEN ${ }^{* *}$ \\ Aydın ÖNAL ${ }^{* * *}$
}

Öz

Araştırmada, Türkiye'de ve Amerika'da ana dili öğretiminde kullanılan Türkçe ve İngilizce ders kitaplarının öğrenme alanlarına göre karşılaştırılması amaçlanmaktadır. Bu amaç doğrultusunda çalışma, nitel araştırma yaklaşımına göre yürütülmüştür. Veri toplama aşamasında doküman incelemesi tekniği kullanılmıştır. Araştırmada veriler dil becerilerine / öğrenme alanlarına göre tasnif edilmiş ve her iki ders kitabı bu doğrultuda karşılaştırıımıştır. Araştırmanın veri kaynağını Millî Eğitim Bakanlığı tarafından yayınlanmış olan 7. sınıf Türkçe ders kitabı ile Amerika'da 7. sınıf düzeyinde kullanılan Prentice Hall Literature Bronze Level adlı kitap oluşturmaktadır. Araştırma sonunda, İngilizce ders kitabının okuma öğrenme alanı hazırlık çalışmalarında ön bilgi ve deneyimleri harekete geçirme, yaşamla ilişkilendirme ve düşünme becerilerini kullandırma yönleri ile Türkçe ders kitabından farklılaştı̆ı̆ tespit edilmiştir. Bunun yanında okuma, dinleme-konuşma ve yazma becerilerinin eğitimine dair Türkçe ve İngilizce ders kitapları arasında önemli farkların olduğu da ortaya konulmuştur.

Anahtar Kelimeler: Ana dili eğitimi, Türkçe, İngilizce, ders kitabı, karşılaştırma.

\begin{abstract}
A Comparative Analysis of Turkish and English Course Books: $7^{\text {th }}$ Grade Sample Abstract

In the research, it is aimed to compare the Turkish textbooks in secondary schools and the English textbooks used in mother tongue teaching in America according to their learning areas. For this purpose, qualitative research approach has been adopted in the study. Document review technique has been used in data collection stage. The data source of the study is composed of the 7th grade Turkish textbook of the secondary school published by the Ministry of National Education and the Prentice Hall Literature Bronze Level which is used at the 7th grade level in the USA. As a result of the study, it has been determined that the English textbook differs from the Turkish textbook in terms of using pre-knowledge and experiences, associating with life and using thinking skills in the preparatory works of the reading learning area. In addition, there are significant differences between Turkish and English textbooks in the education of reading, listening, speaking and writing skills.
\end{abstract}

Keywords: Mother tongue education, Turkish, English, textbook, comparison.

\section{Giriş}

Dil gelişimi ve eğitimi, anne karnında başlar ve ömür boyu devam eder. Çocuklar okul öncesi dönemde dili konuşarak ve dinleyerek kazanır. Okul sıralarına geldiklerinde ise öğretmen rehberliğinde okuma, yazma ve ana dilin diğer inceliklerini edinir. Ana dili öğretiminde dil becerileri (dinleme, konuşma, okuma ve yazma) temele alınmaktadır. Bu becerilerin kazanılmasında ise çeşitli kaynaklara intiyaç vardır. Bu noktada devreye giren ders kitapları hem öğretim programının uygulamaya dönük yüzü hem de dil becerilerinin öğretiminde temel kaynak konumundadır. Bu yönüyle ana dili eğitimi,

\footnotetext{
${ }^{* *}$ Doç. Dr., Giresun Üniversitesi, Eğitim Fakültesi, sedat.maden@giresun.edu.tr, ORCID: 0000-0002-8024-8182

*** Öğretmen, Giresun 15 Temmuz Şehitler İmam Hatip Ortaokulu, aydnonall@gmail.com, ORCID: 0000-00020930-9122
} 
ders kitaplarına bağlı yapılmaktadır. Özellikle "Amerika Birleşik Devletleri'nde eğitim öğretime ayrılan zamanın \%75-90'ının ders kitapları çerçevesinde organize edildiği; Norveç ve İspanya'daki sınıflarda yapılan ders gözlemlerinde de ders kitaplarına oldukça bağımlı ders işlendiği" (Kurt, 2018: 1171), Türkiye'de ise "öğretmenlerin ders araç gereçlerden en çok ders kitaplarını (\%98), öğrenci çalışma kitabını (\%95), öğretmen kılavuz kitabını (\%90) kullandıkları tespit edilmiştir" (Gün, 2013: 565). Eğitimin ana aracı olan ders kitapları öğretim programlarında belirlenen kazanımlara göre hazırlanmaktadır. Bu nedenle ders kitaplarına öğretim programlarının uygulamaya dönük yüzü denilebilmektedir.

Ders kitapları, "hem eğitim hem de öğretim amacıyla kullanılan temel kaynaklardır. Öğrencinin yaş ve bilgi seviyesine uygun bilişsel ve duyuşsal becerilerle donatılmış zengin metinlerden oluşan, öğretim programlarının esas aldığı ilkeler doğrultusunda hazırlanan, ihtiva ettiği bilgileri öğrenciye aktaran basılı eğitim ve öğretim materyalleridir" (Çeçen, Çiftçi ve Melanlıoğlu, 2007: 206). Nitekim “Ana dili öğretimi olarak Türkçenin başarıyla yürütülmesi ilk elden çok iyi düzenlenmiş bir programla ve bu programa bağlı kalınarak hazırlanmış Türkçe ders kitaplarıyla gerçekleştirilebilir” (Demirel, 2007: 11). Tarihsel olarak bakıldığında da yüzyıllarca eğitim yapılan ortamlarda temel kaynak kitaplar olmuştur. Günümüzde ise "teknolojinin sunduğu sınırsız alternatiflere rağmen ders kitapları eğitimde kullanılan en önemli araç olma özelliğini korumaktadır" (Coşkun ve Taş, 2008: 60). Öğretmenler "Türkçe dersinde birçok etkinliği kitap ile başlatıp kitap ile sürdürmektedir" (Yurt ve Arslan, 2014: 318). Öğrenciler de aynı şekilde Türkçe ders kitaplarındaki metinler ve etkinlikler sayesinde temel dil becerilerini geliştirmektedir.

Türkçe ders kitaplarının 21. yüzyılın insanlardan beklediği becerileri kazandırmada yeterli olması ayrıca dikkat edilmesi gereken bir husustur. Bu nedenle ders kitapları öğrencinin eleştirel, yaratıcı, yansıtıcı ve diğer üst düzey becerileri kazanmasında rehber olması gerekir. Nitekim "Türkçe Dersi Öğretim Programı; dil becerilerinin ve yeterliliklerinin geliştirilmesini, diğer tüm alanlarda öğrenme, kişisel ve sosyal gelişme ile mesleki becerileri edinmenin ön şartı olarak kabul etmektedir" (MEB, 2018: 7). Bu açıdan öğretmen için kılavuz, öğrenci için bilgi kaynağı olan ve alıştırma imkânı sunan ders kitaplarının içerik olarak zengin olması önemlidir.

Günümüzde Türkçe dersi kitapları tematik anlayışla oluşturulmaktadır. Tema, aynı duygu ya da düşünceyi içeren konuların bir araya toplanmasından oluşan gruplara verilen ad olarak tanımlanabilir. Türkçe dersi öğretim programında her sınıf düzeyinde 8 tema işlenmesi öngörülmüştür. Bu temalardan; Erdemler, Millî Kültürümüz, Millî Mücadele ve Atatürk temalarının her sınıf düzeyinde işlenmesi zorunludur (MEB, 2018: 16). Bunun dışında eklenecek temalar yazarların isteğine bırakılmıştır. Tematik yaklaşım sayesinde "farklı disiplinlerin aynı temayla ilgili kazanımlarının bir bütün olarak ele alınması, öğrencinin bilgiyi anlamlandırması, ilişkilendirmesi ve üst düzey zihinsel becerilere ulaşması" (Demirbaş 2006: 29) mümkün olabilmektedir. Tematik yaklaşımla hazırlanan Türkçe ders kitabında, öğrenci her temada, temanın farklı yönlerini ele alan metinlerle karşılaşır. Temada yer alan metinler işlendikçe öğrenci, öğrendiği kavramlarla yeni kavramlar arasında ilişki kurar. Böylelikle, metinler aracılığı ile öğrenme gerçekleşir." (Arhan ve Gültekin, 2013: 9). Temalarda farklı türlerde bulunan metinler sayesinde öğrenci dil becerilerini geliştirir. Bu nedenle seçilecek metinlerin öğrencilerin çok yönlü gelişimini sağlayacak nitelikte olması önemlidir. Öğrencinin sadece dil becerilerini değil aynı zamanda ruh dünyasını, ahlaki yönünü, hayal gücünü geliştirebilecek ve sosyalleşmesi için toplum hayatında gerekli becerileri içeren metinlerin ders kitaplarında olması gerekmektedir.

Metinler hem eğitim ortamında hem de günlük hayatta sık kullanılmaktadır. Coşkun (2014: 60) metni, belirli bir iletişim ortamında üreticisi ve alıcısı olan, sözlü ya da yazılı anlamlı dil birlikleri olarak tanımlamaktadır. Güneş (2016: 247) ise bilgi, duygu ve düşüncelerin yerleştirildiği yapı olarak görmekte ve bu yapıların da tesadüfen bir arada olmadığını belirtmektedir. Metinler gerek elektronik gerekse basılı olarak hayatımızda yer edinmiştir. Eğitimin vazgeçilmez unsuru olan metinler, yapılandırmacı anlayışla birlikle öğrencinin üst düzey beceriler kazanmasında, bilgiyi organize edip üretmesinde önemli bir unsur halini almıştır. Eğitim ve öğretim sürecinde yoğun olarak kullanılan metinler ana dil eğitiminde en önemli araçtır. Çünkü öğrenciler dil becerilerini metinler yoluyla edinmektedir. Bu yüzden metinlerin birtakım özellikleri taşıması gerekir. Alanyazında Beaugrande ve Dressler (1981) metinlerde bulunması gereken ölçütleri şu şekilde sıralamaktadır: Bağdaşıklık, tutarlııı, amaçlılık, ikna edicilik, öğreticilik, duruma uygun olma, metinlerarasılık. 2006 Türkçe Dersi Öğretim Programı'nda 
(s.56) da ders kitaplarında yer alacak metinlerin dersin amaçlarına, öğrencilerin ilgi alanlarına ve seviyelerine uygun olma; Türkçenin zenginlik ve güzelliklerini, türün özelliklerini yansıtma; dil bilinci, hayal gücü, estetik zevk ile okuma sevgisi ve alışkanlığı kazandırma gibi niteliklere sahip olması tavsiye edilmiştir. Dolayısıyla bu özellikleri taşıdığı takdirde metinlerin etkili bir öğretim aracı olabileceği açıktır.

Metinlerin ders kitabındaki yerleşimi, yazı büyüklüğü ve kelime sayısı öğrencinin seviyesine uygun olmalıdır. Metnin kenarlarında bulunan resimler metne uygun ve sanatsal nitelikte olması önemlidir. Öğrencide edebî zevki geliştirecek resimlerin metne yönelik ilgiyi artıracağı bir gerçektir. Bu gerçekten hareketle gerek kültürü yansıtan resimlerin gerekse dünya çapında sanatçıların eserlerinin metne uygun bir şekilde, Türkçe ders kitaplarında bulunması gerekmektedir. Bunun yanı sıra metnin anlaşılması ve öğrenciye değer kazandırması için okuma stratejilerinin öğretimi esastır. Metnin öncesinde veya metin okunurken strateji bildiren ifadelerin olması öğrenci için faydalıdır. Her metne uygun farklı stratejilerin kullanılmasını sağlamak öğrencinin metni derinlemesine anlaması için gereklidir. Metne hazırık çalışması, metin sonrası etkinlikler, metnin etrafındaki resimler, metne yönelik stratejiler vb. metni öğretilir kılan unsurlardır.

Metinler, türlerine göre sınıflandırııır ve adlandırılır. Güneş (2016: 248) konuşma veya sözle aktarılanları sözlü metin, yazıyla aktarılanları yazılı metin, resim, şekil, grafik vb. görsel sembollerden oluşanları da görsel metin şeklinde sınıflandırmaktadır. 2018 Türkçe Dersi Öğretim Programı'nda metin türleri; bilgilendirici, hikâye edici ve şiir olarak 3'e ayrılmaktadır. Hazırlanacak Türkçe ders kitaplarının programda belirtilen türleri içermesi gerekmektedir. Bu türlere uygun olarak ders kitabına seçilecek metinlerde öğrencinin yaş ve ilgi seviyesi dikkate alınmalıdır. Zamanla ortaya çıkan yeni metin türlerinin öğrencilerle buluşturulması da ayrı bir önem taşımaktadır. Hazırlanan 2018 Türkçe Dersi Öğretim Programı'nda Efemera ve Broşür (liste, diyagram, tablo, grafik, kroki, harita, afiş vb. karma içerikli metinler) e-posta, Haber Metni, Reklam, Sosyal Medya Mesajları gibi türlerin olması olumlu bir durumdur. Ancak teknolojik gelişmeler, iletişim ve edebiyat alanındaki yeni değerlendirmelerle bunların dışında birçok türün de ortaya çıktığı görülmektedir. Bu nedenle bu türlerin de ders kitaplarında yer bulması gerekmektedir.

Metnin daha iyi anlaşılması ve metinden hareketle dil becerilerinin geliştirilmesi için metin sonlarında etkinlikler bulunmaktadır. Bu sayede öğrencinin dil becerilerine yönelik alıştırma yapması ve metni ne düzeyde anladığı ölçülebilmektedir. Metin bittikten sonra sorulan "sorular, bilimsel ilkeler doğrultusunda alanında uzman kişilerce hazırlandıysa, bir yandan öğrencilerin metni anlayıp anlamadıklarına ilişkin sağ ıklı bir biçimde saptama yapabilmeye, diğer yandan ise öğrencilerin metne çok yönlü bakabilmelerini sağlar." (Ülper ve Yalınkılıç, 2010: 451). Üst düzey becerileri geliştirecek soruların bulunması öğrencinin çok yönlü gelişimine katkı sağlayacaktır. Bu nedenle "metin soruları özellikle 5, 6, 7 ve 8. sınıflar açısından ele alındığında, okul eğitimindeki hedeflere ulaşılması için belirli özellik ve niteliklere sahip olmalıdır. Gerek 5. sınıf gerekse 6. sınıf öğrencilerinin anlama, anlam kurma, fikir ve değer oluşturma kazanımları ele alındığında ders kitaplarında yer alan okuma metinleri ve sorularının öğrencilerin bilişsel gelişimine katkıda bulunacak türden olması gerekir" (Tüm, 2016: 736). Nitekim Türkçe ders kitaplarında metin sonlarında da sorular bulunmaktadır.

Yapılandırmacı anlayışın benimsenmesi ile, Türkçe ders kitapları birçok değişikliğe uğramıştır. Ancak yeterliliği tartışma konusu olmuştur. Gerek fiziki gerek içerik gerekse ölçme ve değerlendirme boyutuyla ders kitaplarının yapılandırmacı anlayıştan uzak bir görüntü çizdiği araştırmacılar tarafından dile getirilmektedir. Nitekim Kırkkılıç ve Maden (2010: 479) ders kitaplarındaki metinlerin öğrenci seviyesi dikkate alınmadan seçildiğini belirtmektedir. Yaylı ve Solak (2009) tarafından metin türleri açısından ders kitaplarını incelediği araştırmada, türlerin dengeli dağıtılmadığı, önemli türlere yer verilmediği, öğrenci seviyesinin göz ardı edildiği, gerçek hayatın ders kitabına aktarılamadığı ifade etmişlerdir. Aytan ve arkadaşları (2018) ise, ders kitabında yer alan metinlerin sadece \%50'sinin öğrencilere rol model olabilecek kahramanlar barındırdığından bahsetmiştir. Melanlıoğlu ve Karakuş Tayşi (2013: 31) de dinlemeye yönelik ölçme ve değerlendirmenin sürece değil sonuca odaklı olduğunu tespit etmiştir.

Ders kitaplarının önemi ve var olan durum birlikte değerlendirildiğinde, Türkçe dersi kitaplarının geliştirilmesi için diğer ülkelerde yararlanılan ve yaygın kullanıma sahip kitaplarla arasındaki benzerlik ve farklılıkların ortaya konulmasında fayda bulunmaktadır. Bu kapsamda, 
Türkiye'de ve dünyada kullanılmakta olan ana dili öğretimi ders kitaplarının incelenmesi ve karşılaştırılarak etkili olabilecek yanların belirlenmesi gereklidir. Alanyazında konuyla ilgili bazı çalışmalar mevcuttur: Örneğin Şimşek (2015) ile Karakuş ve Turgut'un (2017) Türkçe ve İngilizce ders kitaplarını metin, tema ve türlere göre karşılaştırdığı çalışması dikkat çekmektedir. Ayrıca, Kurt'un (2018) Türkiye ve Macaristan'daki dil öğretimi ders kitaplarını karşılaştırdığı çalışma da burada örnek gösterilebilir. Buna karşın ders kitaplarını dil becerileri ya da öğrenme alanlarına göre karşılaştıran, bu yönde ayrıntılı analizler sunan araştırmaların (Güleç ve Demirtaş, 2013; Kalaycı ve Durukan, 2019 gibi) sınırlı olduğu görülmüştür. Bu çalışma ile Türkçe ve İngilizce ders kitapları arasında dil becerilerini geliştirme, çağdaş yaklaşımlara uygunluk, öğrenci seviyesine görelik gibi açılardan ne tür farklıııların ve benzerliklerin olduğu ortaya konulacaktır. Böylece ders kitabı hazırlayanlara yol gösterici tespitler sunulması öngörülmektedir.

Bu araştırmanın amacı, Türkiye'de ve Amerika'da ana dili öğretiminde kullanılan Türkçe ve İngilizce ders kitaplarını öğrenme alanlarına göre karşılaştırmaktır.

\section{Araştırmanın Modeli}

\section{Yöntem}

Çalışma, nitel araştırma yaklaşımına göre yürütülmüştür. Nitel araştırmalarda veriler teker teker okunur, kod ve kategorilere ayrıır ve bu şekilde araştırma sonuçlarııın sunulması sağlanır (Merriam, 1998: 58). Bu desende, araştırılacak konu ya da konular doğal ortamlarında gerçekçi ve bütüncül biçimde anlamlandırılmaya ve yorumlanmaya çalışılır (Ekiz, 2009: 31). Nitekim araştırmada da ana dili öğretiminde kullanılan Türkçe ve İngilizce ders kitapları incelenmiş, belirli başlıklar altında elde edilen veriler gruplandırımış ve bu şekilde karşılaştırılmaya çalışımıştır.

\section{Veri Kaynağı}

Araştırmanın veri kaynağını Millî Eğitim Bakanlığı tarafından yayınlanmış olan Ortaokul ve İmam Hatip Ortaokulu 7. sınıf Türkçe ders kitabı ile Amerika'da 7. sınıf düzeyinde kullanılan Prentice Hall Literature Bronze Level (2000) adlı kitap oluşturmaktadır. Türkiye'de kullanılan Türkçe ders kitaplarından 7. sınıf ders kitabının seçilmesinde, MEB tarafından yayınlanmış ve güncel bir eser olması etkili olmuştur. Prentice Hall Literature Bronze Level adlı eserin belirlenmesinde ise 50 yılı aşkın süredir kullanılan bir kaynak olması dikkate alınmıştır. Ayrıca, öğrenme alanları ve ölçme-değerlendirme özelliklerini örneklendirebilecek, benzer iki tema seçilmiştir: Bunlar Türkçe ders kitabından Kişisel Gelişim, İngilizce ders kitabından ise Kendini Keşfetme temalarıdır.

\section{Verilerin Toplanması ve Analizi}

Araştırmada, nitel araştırmada başvurulan yöntemlerden doküman incelemesi kullanılmıştır. Doküman incelemesi alanyazında "araştırılması hedeflenen olgu ve olgular hakkında bilgi içeren, yazılı ve görsel materyallerin analizini kapsar" (Yıldırım ve Şimşek, 2008: 187-188). Bu doğrultuda çalışmada, veri kaynağı olarak belirlenen ders kitaplarının 1. temaları öğrenme alanları bakımından karşılaştırılmaktadır. Ders kitaplarından elde edilen veriler betimsel olarak analiz edilmeye çalışımıştır.

\section{Bulgular}

Türkçe ve İngilizce ders kitaplarına ilişkin tespitler aşağıda ayrı başlıklar altında sunulmuştur. Bulguların sunulmasında ders kitaplarındaki sıralamaya uyulmuştur:

\section{Türkçe ve İngilizce Ders Kitaplarında Metin Dağılımı}

Türkçe ders kitabında, her temada 3 okuma, 1 serbest okuma ve 1 dinleme metni vardır. Parça ve tema sonlarında ise ölçme ve değerlendirme yönelik etkinlikler mevcuttur. Amerika'da birden fazla eyalette okutulan İngilizce ders kitabında ise toplam 10 tema vardır. Bu temaların içinde 2-8 arasında okuma metni bulunmaktadır. Dinleme metni, serbest okuma metni gibi bir ayrım yapılmamıştır. Parça ve tema sonlarında ölçme ve değerlendirmeye yönelik etkinlikler öğrenme alanlarına göre yer almaktadır. 


\section{Okuma Öğrenme Alanı}

Türkçe ve İngilizce ders kitapları okuma öğrenme alanında, hazırlık, akıcı okuma, söz varlığı ve anlama bölümlerine göre incelenmiştir. Hazırlık çalışmalarına ilişkin bilgiler Tablo 1'de gösterilmiştir:

\section{Hazırlık}

Tablo 1.

Okuma öncesi hazırlık çalışmaları

\begin{tabular}{ll}
\hline Ingilizce Ders Kitabı & Türkçe Ders Kitabı \\
\hline $\begin{array}{l}\text { Connect Your Experience } \\
\text { (Ön Bilgileri Harekete Geçirme) }\end{array}$ & $\begin{array}{l}\text { Gelecek Derse Hazırlık Çalışmaları } \\
\text { (Araştırma ödevi) }\end{array}$ \\
\hline Background For Understanding (Geçmişi Anlama) & Ön Bilgileri Harekete Geçirme \\
\hline Thematic Focus (Temaya Odaklanma) & \\
\hline Literary Focus (Metne Odaklanma) & \\
\hline
\end{tabular}

Tablo 1'de görüleceği üzere, İngilizce ders kitabında 4 farklı başlıkta okuma öncesi bir hazırlık çalışması vardır. Bu etkinlikler, temalara bağı olarak yer verilmiş okuma metinlerinden önce yapılmaktadır. Aynı şekilde Türkçe ders kitaplarında da hazırlık çalışmaları ve ön bilgileri harekete geçirici etkinlikler mevcuttur. Bu yönüyle İngilizce ve Türkçe ders kitapları benzerdir. Ancak İngilizce ders kitabında, geçmişi anlama, odaklanma, metne yönelik bilgilendirici paragraf oluşturma gibi birçok üst düzey düşünme becerisi işe koşan etkinliklere de yer verilmektedir.

İngilizce ders kitabında hazırlık çalışmaları geniş yer tutmaktadır. Kitapta Ön Bilgileri Harekete Geçirme başlığı altında öğrencinin metinde geçen konuyla geçmiş deneyimleri arasında bağlantı kurulması hedeflenmektedir. Yine Geçmişi Anlama kısmında metinde verilecek mesajın daha iyi anlaşılmasına yönelik tarih ile bağlantı kurularak disiplinler arası bir yaklaşım sergilenmiştir. Metin öncesi bu çalışmalar sayesinde öğrencinin bilişsel yönden metne ısınması, kendini hazır hâle getirmesi daha kolay olacaktır.

İngilizce ders kitabında etkinlik veya çalışma adı altında olmasa da metin öncesinde görseller mevcuttur. Bu görseller sayesinde öğrenci, zihninde metne yönelik imgeler oluşturabilecektir. Görsel zekâya sahip öğrenciler için bu görseller daha da büyük öneme sahiptir. Bu açıdan İngilizce ders kitabının metin öncesi çalışmalarında çoklu zekâ kuramının da dikkate alındığı söylenebilir.

İngilizce ders kitabında öğrencinin okuyacağı metinle ilgili gerçek yaşamı, farklı disiplinlere dair bilgileri ve deneyimleri arasında bağ kurması ve böylece içeriği net olarak kavraması hedeflenmektedir. Bu bulgu, İngilizce ders kitabında öğrenci merkezliliğin hâkim olduğunu göstermektedir.

Türkçe ders kitabında metin öncesi hazırlık çalışmaları olduğu belirlenmiştir. Ders kitabının tümünde "Derse Hazırık" kısmında bu şekilde sorular sorulmaktadır. Bu sorularla günlük hayata yönelik bağlantılar kurulmak istenilmektedir. Bazı metinlerden önce de Gelecek Derse Hazırlık başlığı altında araştırma ödevleri verilmektedir. Ancak elde edilen bilgilerin nasıl kaydedileceği, dersle nasıl ilişkilendirileceği ve sunulacağı net değildir.

İngilizce ders kitabının okuma öncesi hazırlık çalışmaları sorulardan ziyade öğrencileri düşünmeye, ilişkilendirme ve hayal etmeye yöneltecek parçalar ve görseller içermektedir. Yine Türkçe ders kitabında metni okuma ve etkinlik çalışmaları bittikten sonra gelecek derse hazırlık için birtakım ödevler ve görevler verilmektedir. Ancak İngilizce ders kitabında gelecek derse hazırlık gibi bir bölüm bulunmamaktadır. Ders kitabında bunu karşılayacak birçok metin öncesi etkinlik vardır.

Ingilizce ders kitabının okuma öncesi hazırlık çalışmalarının öğrencilerin ön bilgi ve deneyimlerini harekete geçirme, yaşamla ilişkilendirme ve düşünme becerilerini kullandırmaya yönleri öne çıkmaktadır. Türkçe ders kitabında ise, sadece açık uçlu sorularla metne hazırlı̆ın sağlanmaya çalışıldığı görülmektedir. 


\section{Akıcı Okuma}

İngilizce ders kitabındaki okuma stratejileri Tablo 2'de belirtilmiştir:

Tablo 2.

Ingilizce Ders Kitabındaki Okuma Stratejileri

\begin{tabular}{ll}
\hline Strateji & Açıklama \\
\hline $\begin{array}{l}\text { Break Down Long Sentences } \\
\text { (Uzun Cümleleri Bölme) }\end{array}$ & $\begin{array}{l}\text { Bu strateji, cümleyi kelime kelime değil sözcüklerin } \\
\text { grup olarak okunması gerektiğini ifade etmektedir. } \\
\text { Aynı şekilde metinde geçen anahtar kelimelerin tespit } \\
\text { edilmesi anlamayı kolaylaştıracağını ifade etmektedir. }\end{array}$ \\
\hline $\begin{array}{l}\text { Apply Word Identification } \\
\text { (Kelime Tanıma) }\end{array}$ & $\begin{array}{l}\text { Anlamı bilinmeyen kelimeler hecelere bölündüğünde } \\
\text { kelimenin anlamı ortaya çıkabileceği ifade } \\
\text { edilmektedir. }\end{array}$ \\
\hline Spelling Strategy (Heceleme Stratejisi) & $\begin{array}{l}\text { Bağlamdan Hareketle Anlamı Bilinmeyen Kelimeleri } \\
\text { Bulma }\end{array}$ \\
\hline $\begin{array}{l}\text { Use Context to Determine Meaning } \\
\text { (Bağlamdan Hareketle Anlamı Belirleme) }\end{array}$ & Dil Bilgisi Etkinlikleri Yapma \\
\hline \multirow{2}{*}{$\begin{array}{c}\text { Reread or Read Ahead } \\
\text { (Tekrar Oku ya da Okumaya Devam Et) }\end{array}$} & $\begin{array}{l}\text { Metinde geçen ifadeler anlaşılmazsa tekrar okunmalı } \\
\text { veya metinle ilgili bir soru sorulduğunda okumaya } \\
\text { devam edilip okurken cevap bulunabileceği } \\
\text { belirtilmiştir. }\end{array}$ \\
\hline
\end{tabular}

Ingilizce ders kitabında okuma stratejileri geniş yer tutmaktadır. Her temada farklı okuma stratejileri mevcuttur. Her metin öncesinde stratejiler Reading Strategy başlığı altında verilmektedir. Aynı zamanda bu stratejiler metnin yanında da verilmektedir. Okuma stratejilerinin ayrıntılı ve temametinlere göre yapılandırılması metnin daha iyi anlaşılmasına hizmet etmektedir.

İngilizce ders kitabında her metne yönelik farklı stratejilerin (sözcük tanıma, yeniden okuma vb.) verildiği görülmektedir. Kitapta dikkat çeken hususların başında, metnin öncesinde okuma stratejilerinin verilmesi, açıklanması ve gerektiğinde örnekler verilmesidir. Bunun yanında metnin kenarlarında bulunan okuma stratejileri ile metnin daha iyi anlaşılması hedeflenmiştir.

Türkçe ders kitabındaki okuma stratejileri Tablo 3'te gösterilmiştir:

Tablo 3.

Türkçe ders kitabındaki okuma stratejileri

Okumaya Yönelik Stratejiler

Metni okurken kendinizi ana kahramanın yerine koyarak onun hislerini anlamaya çalışınız. (Empatik okuma)

Metni, noktalama işaretlerine dikkat ederek sesli okuyunuz. (Sesli okuma)

Türkçe ders kitabında her temada okuma ve dinleme metinleri içinde stratejilere rastlanmaktadır.Türkçe ders kitabında "Metni, noktalama işaretlerine dikkat ederek sesli okuyunuz." ve "Metni okurken kendinizi ana kahramanın yerine koyarak onun hislerini anlamaya çalışınız." şeklinde empatik ve sesli okuma stratejilerine ilişkin yönergeler bulunmaktadır. Bu okuma stratejileri metin öncesinde verilmektedir. Metnin okunduğu sırada bu stratejiler metnin bulunduğu sayfanın kenarlarında verilmemektedir. Ayrıca bu stratejilerin nasıl kullanılacağına yönelik metin öncesinde açıklayıcı ifadeler ve örneklendirmeler de yoktur. Türkçe ders kitabı bu yönüyle İngilizce ders kitabından farklılık göstermektedir.

Her iki ders kitabında okuma stratejisi kullanılmaktadır. İngilizce ders kitabında stratejiler için metin öncesinde ayrı bir bölüm ayrılmakta ve örneklerle nasıl kullanılacağı anlatılmaktadır. Yine bu ders kitabında strateji öğretimi, metin öncesinde olduğu gibi sayfa kenarlarında verilmek suretiyle okuma 
esnasında da sürdürülmektedir. Her metne göre farklı stratejiler verilmekte ve strateji verilmeyen metin de bulunmamaktadır.

Türkçe ders kitabında ise, okuma metinlerinde stratejiler var iken, serbest okuma metinlerinde yoktur. Stratejiler bakımından İngilizce ders kitabının Türkçe ders kitabından daha zengin ve süreç temelli olduğu söylenebilir. Yine Türkçe kitabından farklı olarak bu stratejilerin nasıl kullanılacağının örneklerle açıklanması da dikkat çeken bulgulardandır.

\section{Söz Varlığı}

Söz varlığına ilişkin bulgular Tablo 4'te gösterilmiştir:

Tablo 4.

Söz varlığı çalışmaları

\begin{tabular}{ll}
\hline İngilizce Ders Kitabı & Türkçe Ders Kitabı \\
\hline Word Bank (Kelime Bankası) & Anlamı Bilinmeyen Kelimeyi Bulma Çalışması \\
\hline Prefixes (Kelime Türetme) & Atasözü, Deyim, Özdeyiş Bulma Çalışmaları \\
\hline Spelling Strategy (Heceleme Stratejisi) & $\begin{array}{l}\text { Bağlamdan Hareketle Anlamı Bilinmeyen } \\
\text { Kelimeleri Bulma }\end{array}$ \\
\hline & Dil Bilgisi Etkinlikleri Yapma \\
\hline
\end{tabular}

İngilizce ders kitabında söz varlığına yönelik çalışmalar Kelime Hazinesi Oluşturma başlığı altında metin öncesinde verilmektedir. Yine okuma metninden sonra da söz varlığına ilişkin etkinliklerin olduğu görülmektedir. Türkçe ders kitabında ise, metin öncesinde söz varlığına yönelik etkinlik yoktur. Bunun yerine metin sonunda etkinliklerin içinde çalışmalar mevcuttur.

Tablo 4'te görüldüğü üzere, İngilizce ders kitabında söz varlığına yönelik Word Bank (Sözcük Bankası-Anahtar Kelime), Önekler-Kelime Türetme ve Heceleme Stratejisi gibi etkinlikler vardır. Türkçe kitabında ise, Anlamı Bilinmeyen Kelimeyi Bulma, Tahmin, Atasözü, Deyim, Özdeyiş Bulma Çalışmaları, Bağlamdan Hareketle Anlamı Bilinmeyen Kelimeleri Bulma gibi etkinlikler vardır.

ingilizce ders kitabında söz varlığına yönelik etkinlikler; anahtar kelimleler, ek-kök ilişkisi ile anlamı bulma, kelime ağı gibi çalışmalar üzerine inşa edilmiştir. Bu etkinlikler metin öncesinde ve metin sonrasında bulunmaktadır. Bunun yanı sıra, anlamı bilinmeyen kelimelerin metnin alt kısmında verildiği kelime ağı yöntemi kullanılarak kelime köklerinden türeyen sözcüklerin metinden bulunmasına çalışılmaktadır.

Türkçe ders kitabındaki söz varlığına ilişkin etkinlikler, metinden sonra yani etkinlikler kısımında yer almaktadır. Metin öncesinde ve metnin kenarlarında İngilizce ders kitabında olduğu gibi etkinlikler yoktur.

Türkçe ders kitabında metinde geçen kelime ve deyimlerin öğretimi için bağlamdan hareketle anlamı bilinmeyen kelimeleri bulmaya yönelik bir etkinliğe başvurulduğu tespit edilmiştir. Yine ders kitabında yeni kelimelerin öğretiminde, tahmin etme, sözlük kullanımı ve cümle içinde kullanma gibi bir sıralamanın izlendiği de görülmektedir.

Her iki ders kitabında da söz varlı̆ı̆nı zenginleştirmeye önem verildiği söylenebilir. İngilizce ders kitabında metin öncesi, metin sırası ve metin sonrasında söz varlığı etkinliklerine yer verilmiştir. Türkçe kitabında ise sadece metinden sonra sözcük çalışmalarına rastlanmaktadır.

\section{Anlama}

Ingilizce ders kitabında sayfa kenarlarında Literary Focus (Metne Odaklanma) ve Literature and Your Life (Metin ve Yaşamınız) adıyla metni anlamaya yönelik anahtar sorular mevcuttur. Yine metnin kenarlarında Critical Viewing (Eleştirel Bakış) adıyla düşünme becerilerini harekete geçiren soruların olduğu kısımlar bulunmaktadır. İngilizce ders kitabında etkinlik kısmında Check Your Comprehension 
(Anladıklarınızın Kontrolü) başığı ile sorular da bulunmaktadır. Bu kısımda metne ilişkin sorular sorularak metnin daha iyi anlaşılmasının hedeflendiği görülmektedir. Bunlarla birlikte İngilizce ders kitabında metin kenarlarında düşünme becerileri harekete geçirmek için Critical Viewing (Eleştirel Bakış) etkinliği verilmiştir. Bu etkinlik içerisinde öğrencilerin metinle ilgili değerlendirme ve çıkarım yapmalarına yönelik soru yöneltilmektedir. Tüm kitapta metinlerin uygun yerlerinde ilişki sırasıyla speculate (şaşırtıcı fikir), connect (ilişki kurma), infer (sonuç çıkarma), evaluate (değerlendirme) ve compare and contrast (karşılaştırma ve çelişki oluşturma) düşünme becerileri ve bu becerilere dönük soruların sıralandığı belirlenmiştir. İngilizce ders kitabında, metinden sonraki etkinlik bölümünde Check Your Comprehension (Anladıklarınızın Kontrolü) kısmında, metin ile ilgili soru sorulmakta ve öğrencinin metni ne ölçüde anladığını kontrol etmesi hedeflenmektedir.

Türkçe ders kitabında anlamaya yönelik sorunlara metin sonundaki etkinliklerde yer verildiği tespit edilmiştir. Yine ders kitabında metnin konusunu ve ana fikrini buldurmaya yönelik boşluk doldurmalı soru içeren etkinlikler de bulunmaktadır. Her iki ders kitabında da metinden sonraki etkinlikler içinde anlamaya yönelik soruların bulunduğu görülmüştür. Diğer taraftan Türkçe ders kitabında metin okunurken herhangi bir anlama çalışması yok iken, İngilizce kitabında metin okunurken metni anlamaya yönelik sorular sunulmaktadır. Bununla beraber Türkçe ders kitabında metin işlenirken düşünme becerilerinin basamaklarını kapsayan sorular bulunmamaktadır. İngilizce ders kitabında ise, tüm metinlerde düşünme becerilerine ilişkin açıklamaların olduğu belirlenmiştir. Düşünme becerilerinin kullanımı açısından İngilizce ders kitabının Türkçe kitabından ayrıldığı söylenebilir.

\section{Konuşma ve Dinleme Öğrenme Alanı}

İngilizce ders kitabında konuşma ve dinleme alanına yönelik çalışmalar metin sonundaki etkinlik kısmında yapılmaktadır. İki öğrenme alanı ayrı tutulmayıp tek başlık altında sunulmuştur. İngilizce kitabında Türkçe kitabında yer alan dinleme metinleri bulunmamaktadır. Dinleme öğrenme alanı konuşma etkinliklerinin içinde verilmiştir. Konuşma ve dinleme becerilerinin öğretiminde stratejilerin kullanılmasına yönelik bir yaklaşım yoktur. Etkinlikler Speaking and Listening başlığı altında toplanmaktadır. Bu kısımda sunulan etkinliklerin yaşamla ilişkilendirme ve günlük yaşamda karşılaşılacak nitelikle olduğu söylenebilir.

İngilizce ders kitabında, konuşma ve dinleme etkinlikleri tarih, müzik, medya gibi farklı konularla ilişkilidir. Ayrıca bireysel ve grupla yapılacak etkinlikler içermektedir. Bu etkinlikler içinde elektronik kaynak kullanımına yer verilmesi de dikkat çekicidir. Kitapta geçen Social Studes Link, Performing Arts Link, Health Link ifadeleri öğrencilerin metinle ilgili internet kaynaklarına yönlendiren site köprüleridir. Bu linkler aracılığıyla, öğrenci şifresi ile ilgili sitelere girmekte, konuyu daha farklı kaynaklardan bilgi alarak, örnekler görerek ve etkinlikler yaparak kavrayabilmektedir. İnternet bağlantılarının özellikle dinleme ve konuşma çalışmalarında olması bu becerilerin uygulama yaparak ya da örneklerini görerek geliştirilebileceğinin dikkate alındığını da göstermektedir. Bu özelliği ile, İngilizce ders kitabının elektronik kaynak kullanımını öğretim sürecine dahil ettiği söylenebilir.

Projects (Projeler) başlı̆ı altında farklı öğrenme alanlarına yönelik etkinliklerin olduğu görülmektedir. Bu etkinlikler içinde Television Soundtrack (Televizyon Müziği) dinleme ve izleme alanına yöneliktir. Kitapta metinden hareketle öğrenciden bir proje hazırlaması istenilmektedir. Dinleme ve konuşma ile ilgili proje konuları arasında, televizyon ve müzik unsurlarının olması öğrencilerinin ilgilerinin ve teknoloji yatkınlıklarının önemsendiği de göstermektedir.

İngilizce ders kitabında yer alan konuşma ve dinlemeye yönelik metinler, türleri, etkinlikler ve bu etkinliklerin öğretiminde kullanılan yöntem ve teknikler Tablo 5'te gösterilmiştir: 
Tablo 5.

ingilizce ders kitabındaki dinleme-konuşma metin ve etkinlikleri

\begin{tabular}{|c|c|c|c|}
\hline Metin Adı & Metin Türü & Etkinlikler & $\begin{array}{l}\text { Etkinliklerde Yöntem ve } \\
\text { Teknikler }\end{array}$ \\
\hline $\begin{array}{l}\text { The Cat Who Thought She Was a Dog } \\
\text { and The Dog Who Thought He Was a Cat } \\
\text { (Köpek Olduğunu Düşünen Kedi ve Bir } \\
\text { Kedi Olduğunu Düşünen Köpek) }\end{array}$ & $\begin{array}{l}\text { Short Story } \\
\text { (Hikâye) }\end{array}$ & 1-Drama & $\begin{array}{l}\text { 1-Kendini Başkasının } \\
\text { Yerine Koyarak } \\
\text { Konuşma }\end{array}$ \\
\hline Two Kinds (iki Çeşit) & $\begin{array}{l}\text { Short Story } \\
\text { (Hikâye) }\end{array}$ & $\begin{array}{l}\text { 1-Konferans } \\
\text { 2-Monolog } \\
\end{array}$ & $\begin{array}{l}\text { 1-i̇şbirlikçi Öğrenme } \\
\text { 2-Rol Oynama }\end{array}$ \\
\hline From Song of Myself (Şarkımdan) & Poem (Şiir) & \multirow{3}{*}{$\begin{array}{l}\text { 1- Telefonda } \\
\text { Konuşma } \\
\text {-2-Panel }\end{array}$} & \multirow{3}{*}{$\begin{array}{l}\text { 1-Serbest Konuşma } \\
\text { 2-Tartışma }\end{array}$} \\
\hline I’m Nobody (Hiç Kimseyim) & Poem (Şiir) & & \\
\hline Me (Bana) & Poem (Şiir) & & \\
\hline $\begin{array}{l}\text { My Furthest-Back Person (En Uzağımda - } \\
\text { Arkamdaki Kişi) }\end{array}$ & $\begin{array}{l}\text { Non-Fiction } \\
\text { (Bilgilendirici } \\
\text { Metin) }\end{array}$ & $\begin{array}{l}\text { 1-Hikâye } \\
\text { Halkası } \\
2- \\
\text { Konuşmacının } \\
\text { Tanıtımı } \\
\end{array}$ & 1-i̇şbirlikçi Öğrenme \\
\hline The Third Level (Üçüncü Seviye) & $\begin{array}{l}\text { Short Story } \\
\text { (Hikâye) }\end{array}$ & $\begin{array}{l}\text { 1-Sözlü Tarih } \\
\text { 2-Boş Zaman } \\
\text { Çalışması } \\
\end{array}$ & $\begin{array}{l}\text { 1-Yaratıcı Konuşma } \\
\text { 2- İşbirlikçi Öğrenme }\end{array}$ \\
\hline $\begin{array}{l}\text { King Arthur: The Marvel of The Sword } \\
\text { (Kral Arthur: Harika Kılıç) }\end{array}$ & $\begin{array}{l}\text { Legend } \\
\text { (Efsane) }\end{array}$ & 1-Drama & $\begin{array}{l}\text { 1-Kendini Başkasının } \\
\text { Yerine Koyarak } \\
\text { Konuşma } \\
\text { 2-İkna Edici Konuşma } \\
\text { 3-İşbirlikçi Öğrenme }\end{array}$ \\
\hline
\end{tabular}

Tablo 5'te İngilizce ders kitabında hikâye, şiir, bilgilendirici metin türlerine yönelik zengin ve çeşitli etkinliklerin olduğu görülmektedir. Kitapta 4 farklı şiir metni aynı etkinliklere bağlanmıştır. Bunlar da Telefonda Konuşma ve Panel'dir. Bunların dışında konferans, monolog, sözlü tarih, boş zaman çalışması ve drama etkinlikleri de yer almaktadır. Yöntem ve tekniklere bakıldı̆̆ında iş birlikli öğrenme, rol oynama ve empati kurma ön plandadır. Empatik konuşma, tartışma, serbest konuşma, ikna edici konuşma, yaratıcı konuşma gibi teknikler de yer almaktadır. Bu bulgudan hareketle, İngilizce ders kitabının yöntem ve teknik çeşitliliği ve elektronik kaynak kullanımı açısından becerilerin öğretimine elverişli bir ortam sunduğu söylenebilir.

Tablo 6.

Türkçe ders kitabındaki metinler ve dinleme etkinlikleri

\begin{tabular}{lccc}
\hline Metin Adı & Metin Türü & Etkinlikler & $\begin{array}{c}\text { Yöntem ve } \\
\text { Teknikler }\end{array}$ \\
\hline Barış Manço & Biyografi & - & - \\
\hline Sol Ayağım & Hikâye & - & - \\
\hline İnsanlarla Geçinme Sanatı & Deneme & - & - \\
\hline $\begin{array}{l}\text { Naim Süleymanoğlu } \\
\text { (Dinleme Metni) }\end{array}$ & Biyografi & - & - \\
\hline Üç Soru (Serbest Okuma Metni) & Masal & - & - \\
\hline
\end{tabular}


Tablo 6'da Türkçe ders kitabında hikâye, deneme, biyografi ve masal türleri için örnek metinler yer aldığı görülmektedir. Bu metinlere bağlı olarak kitapta konuşma ve dinleme etkinlikleri bulunmamaktadır. Ayrıca ne metin öncesi ne metin işlenirken ne de etkinlikler kısmında konuşma ve dinlemeye yönelik bir çalışma vardır. Naim Süleymanoğlu, dinleme metni olmasına rağmen etkinliklerinde dinlemeye yönelik herhangi bir etkinliğin olmaması oldukça dikkat çekicidir. Bu bulgu, dinleme ve izlemeye yönelik öğrenme-öğretme çalışmalarının öğretmen tercihine bırakıldığını göstermektedir.

İngilizce ders kitabında ise etkinlikler ve bu etkinliklerde kullanılacak yöntem ve teknikler oldukça ayrıntılı biçimde planlanmıştır. Ayrıca, kitabın basım yılı dikkate alındığında, elektronik kaynak kullanımına yönelik linkler içermesi de önemli bir özelliktir. Türkçe ders kitabı ise, 2018 yılında basılmış olmasına rağmen elektronik kaynaklar sadece dinleme / izleme metinlerinin dinletilmesi için kullanılmaktadır.

\section{Yazma Öğrenme Alanı}

Türkçe ve İngilizce ders kitaplarındaki tüm metinlere ait tür, yöntem ve tekniklere ilişkin bulgular Tablo 7, 8, 9 ve 10' da gösterilmiştir:

Tablo 7.

ingilizce ders kitabındaki türler

\begin{tabular}{|c|c|}
\hline Yazılı Anlatım Türleri & Metinler \\
\hline \multirow[b]{2}{*}{ Description (Açıklama) } & Observation (Gözlem) \\
\hline & $\begin{array}{l}\text { Remembrance of People and Place } \\
\text { (Yer veya insanlara yönelik detaylar) }\end{array}$ \\
\hline \multirow{3}{*}{ Narration (Öyküleme) } & Firsthand Biography (Biyografi) \\
\hline & Shorty Story (Hikâye) \\
\hline & Autobiographical Incident (Otobiyografik Olay) \\
\hline \multirow{5}{*}{ Exposition (Yorumlama) } & Summary (Özet) \\
\hline & Classification (Sınıflandırma) \\
\hline & How to Composition (Kompozisyon Nasıl Yazılır?) \\
\hline & Comparison and Contrast Essay (Karşılaştırma) \\
\hline & $\begin{array}{l}\text { Written Solution to a Problem } \\
\text { (Bir Problemin Yazılı Çözümü) }\end{array}$ \\
\hline \multirow{3}{*}{ Persuasion (ikna Edici Yazma) } & Advice Column (Tavsiye ve Öneri) \\
\hline & Advertisement (Reklam) \\
\hline & $\begin{array}{l}\text { Essay Supporting an Opinion } \\
\text { (Bir Fikri Destekleyen Deneme) }\end{array}$ \\
\hline \multirow{3}{*}{ Reports (Araştırma Raporları) } & Lab / Experiment Report (Deney Raporu) \\
\hline & $\begin{array}{l}\text { Library Research Report } \\
\text { (Kütüphane Araştırma Raporu) }\end{array}$ \\
\hline & Experiment Report (Deney Raporu) \\
\hline \multirow{3}{*}{ Creative (Yaratıcı Yazma) } & Song Lyrics (Şarkı Sözleri) \\
\hline & Poem (Şiir) \\
\hline & Monologue (Monolog) \\
\hline \multirow{2}{*}{$\begin{array}{l}\text { Response to Literature } \\
\text { (Literatüre Yanıt) }\end{array}$} & $\begin{array}{l}\text { Reader's Response Journal Entry } \\
\text { (Okuyucu Günlüğü) }\end{array}$ \\
\hline & Letter to an Author (Yazara Mektup) \\
\hline
\end{tabular}

Tablo 7'ye göre, İngilizce ders kitabında 7 farklı yazılı anlatım türüne yer verildiği görülmektedir. Bu kitapta yer alan Deney Raporu, Şarkı Sözü, Monolog, Okuyucu Günlügü, Yazara Mektup, Kütüphane Araştırma Raporu ve Kompozisyon Nasıl Yazııır? gibi metin türlerinin Türkçe ders kitabında bulunmadığı 
da belirlenmiştir. İngilizce ders kitabındaki türler incelendiğinde, öğrencilerin günlük ihtiyaçlarının ve iş hayatındaki gereksinimlerinin önemsendiği anlaşılmaktadır. Bu bulgudan hareketle, İngilizce ders kitabının metin türü bakımından zengin olduğu söylenebilir.

Tablo 8.

Türkçe ders kitabındaki türler

\begin{tabular}{lll}
\hline Yazılı anlatım türleri & Metinler & \\
\hline & Anı & Reklam \\
& Kılavuzlar & Sosyal Medya Mesajları \\
& Blog & Biyografiler, Otobiyografiler \\
& Gezi Yazısı & Dilekçe \\
Bilgilendirici Metinler & Efemera ve Broşür & Günlük \\
& Makale / Fıkra / Söyleşi / & Haber Metni \\
& Deneme & Özlü Sözler \\
& e-posta & \\
& Mektup & \\
& Mizahi Fıkra & Hikâye \\
& Masal / Efsane / Destan & Karikatür \\
\hline \multirow{3}{*}{ Hikâye edici metinler } & Fabl & \\
& Şiir & Şarkı / Türkü \\
& Tekerleme / Sayışmaca / & \\
\hline \multirow{3}{*}{ Şiir } & Bilmece & \\
&
\end{tabular}

Tablo 8'de görüleceği üzere, Türkçe ders kitabındaki türler bilgilendirici metinler, hikâye edici metinler ve şiir olarak üçe ayrılmaktadır. Bu türler için ise, birden fazla metin örneğine kitapta yer verilmektedir. Ayrıca kitapta e-posta, sosyal medya mesajları gibi elektronik ortamda kullanılabilecek metin türleri bulunmaktadır.

İngilizce ders kitabında bulunan yazılı anlatım türleri, etkinlikler ve başvurulan yöntem ve teknikler Tablo 9'da gösterilmiştir:

Tablo 9.

Ingilizce ders kitabındaki yazılı anlatım türleri, etkinlikler ve başvurulan yöntem-teknikler

\begin{tabular}{|c|c|c|c|c|}
\hline Metin Adı & Türü & Yazma Etkinlikleri & $\begin{array}{l}\text { Etkinliklerdeki } \\
\text { Türler }\end{array}$ & $\begin{array}{l}\text { Yöntem ve } \\
\text { Teknikler }\end{array}$ \\
\hline \multirow{2}{*}{\multicolumn{2}{|c|}{$\begin{array}{l}\text { The Cat Who Thought She } \\
\text { Was a Dog and The Dog Who }\end{array}$}} & 1-Reklam Yazma & 1- Bilgilendirici & \multirow{6}{*}{$\begin{array}{l}\text { 1-İş birlikli Yazma } \\
\text { 2-Metin } \\
\text { Tamamlama }\end{array}$} \\
\hline & & 2-Gazeteye & (Description) & \\
\hline Thought He Was a Cat & Hikâye & Makale Yazma & 2-ikna Edici & \\
\hline (Köpek Olduğunu Düşüne & n(Short Story) & 3-Broşür Yazma & (Persuasion) & \\
\hline Kedi ve Kedi Olduğunu & & 4-Rapor Yazma & 3-Öyküleyici & \\
\hline Düşünen Köpek) & & 5-Fabl yazma & (Narration) & \\
\hline Two Kinds (iki Çeşit) & $\begin{array}{l}\text { Hikâye } \\
\text { (Short Story) }\end{array}$ & $\begin{array}{l}\text { 1-Günlük Yazma } \\
\text { 2-Paragraf Yazma } \\
\text { 3-Rapor Yazma }\end{array}$ & $\begin{array}{l}\text { 1- Bilgilendirici } \\
\text { (Description) } \\
\text { 2- Öyküleyici } \\
\text { (Narration) }\end{array}$ & $\begin{array}{l}\text { 1-Kontrollü Yazma } \\
\text { 2-Güdümlü Yazma }\end{array}$ \\
\hline $\begin{array}{l}\text { From Song of Myself } \\
\text { (Şarkımdan) }\end{array}$ & Şiir (Poem) & \multirow{3}{*}{$\begin{array}{l}\text { 1-Kural ve Plan } \\
\text {-Yazma }\end{array}$} & $\begin{array}{l}\text { 1- Sergi: } \\
\text { Bağlantı Kurma }\end{array}$ & \multirow{3}{*}{$\begin{array}{l}\text { 1-Boşluk } \\
\text { Doldurma }\end{array}$} \\
\hline $\begin{array}{l}\text { I'm Nobody } \\
\text { (Hiç Kimseyim) }\end{array}$ & Şiir (Poem) & & $\begin{array}{l}\text { (Exposition: } \\
\text { Making } \\
\text { Connection) }\end{array}$ & \\
\hline Me (Bana) & Şiir (Poem) & & $\begin{array}{l}\text { 2-Sergi: Bilgi } \\
\text { Verme }\end{array}$ & \\
\hline
\end{tabular}




\begin{tabular}{|c|c|c|c|c|}
\hline & & & $\begin{array}{l}\text { (Exposition: } \\
\text { Giving } \\
\text { Information) }\end{array}$ & \\
\hline $\begin{array}{l}\text { My Furthest-Back Person } \\
\text { (En Uzağımda -Arkamdaki } \\
\text { Kişi) }\end{array}$ & $\begin{array}{l}\text { Bilgilendirici } \\
\text { Metin } \\
\text { (Non -fiction) }\end{array}$ & $\begin{array}{l}\text { 1-Altyazı yazma } \\
\text { 2-Kitap Etiketi } \\
\text { Yazma } \\
\text { 3-Öneri/Teklif } \\
\text { Yazma }\end{array}$ & $\begin{array}{l}\text { 1- Sergi: Bilgi } \\
\text { Verme } \\
\text { (Exposition: } \\
\text { Giving } \\
\text { Information) } \\
\text { 2-ikna Edici } \\
\text { (Persuasion) }\end{array}$ & 1-Kontrollü Yazma \\
\hline The Third Level (Üçüncü & Hikâye (Short & $\begin{array}{l}\text { 1-Mektup Yazma } \\
\text { 2-Kısa Öykü Yazma }\end{array}$ & $\begin{array}{l}\text { 1- Bilgilendirici } \\
\text { (Description) }\end{array}$ & $\begin{array}{l}\text { 1-Kelime ve } \\
\text { Kavram }\end{array}$ \\
\hline Seviye) & Story) & 3-Rapor Yazma & $\begin{array}{l}\text { 2-Öyküleme } \\
\text { (Narration) }\end{array}$ & $\begin{array}{l}\text { Havuzundan } \\
\text { Seçerek Yazma }\end{array}$ \\
\hline $\begin{array}{l}\text { King Arthur: The Marvel of } \\
\text { The Sword (Kral Arthur: } \\
\text { Harika Kılıç) }\end{array}$ & $\begin{array}{l}\text { f Efsane } \\
\text { (Legend) }\end{array}$ & 1-Nutuk Yazma & $\begin{array}{l}\text { 1-Bilgilendirici } \\
\text { (Description) }\end{array}$ & $\begin{array}{l}\text { 1-Güdümlü Yazma } \\
\text { 2-Yaratıcı Yazma }\end{array}$ \\
\hline
\end{tabular}

Tablo 9'da İngilizce ders kitabında her metin için zengin ve çeşitli etkinliklerin verildiği görülmektedir. Kitapta hikâye türündeki metinler için 3 ile 5, şiir ve efsane türü metinler için 1 yazma etkinliği yer almaktadır. Etkinliklerde oluşturulan metin türleri de çeşitlidir. Kitabın tümünde en fazla yazma öğrenme alanında etkinliğin bulunması dikkat çekmektedir. Tablo $9^{\prime}$ da da görüldüğü gibi, metin türünün dışındaki türlerde metinler içeren etkinliklerle öğrencilere uygulama yaptırılması dikkat çekmektedir. Söz gelimi, öyküleyici bir metin işlenirken etkinliklerde bilgilendirici ve ikna edici yazma çalışmalarına rastlanabilmektedir. Böylece kitapta tüm yazııı anlatım türleri birlikte kullanılarak örnek metnin kavratılmasına çalışılmaktadır. Bunların yanında, İngilizce ders kitabında yazma çalışmalarında iş birlikli öğrenme, metin tamamlama, boşluk doldurma, kontrollü, güdümlü, kelime havuzu ve yaratıcı yazma tekniklerinin uygulandığı da tespit edilmiştir. Bu bulgu, İngilizce kitabının metin türü ve yazma etkinlikleri bakımından ayrıntılı ve zengin bir içeriğe sahip olduğunu göstermektedir. İngilizce ders kitabındaki yazma etkinliklerinin Build Your (İnşa edin) bölümü Fikir Bankası başlığına bağlı Writing (Yazma) adıyla 3 farklı bölümde gerçekleştirildiği tespit edilmiştir. Tablo 9'da görüldüğü gibi, bu çalışmalar mektup yazma, kısa gezi yazısı yazma ve psikayatri raporu yazma gibi olarak belirlenmiştir. Çalışmalar metinle ilişkilendirilmiş ve nasıl yapılacağı da açıklanmıştır. Yine bu kitapta Projects başlı̆ı altında, elektronik kaynak linkleri verilerek 3 farklı yazma çalışmasının yapılması hedeflenmektedir. Etkinlik incelendiğinde, internet kaynaklarından yararlanarak farklı konu alanları ve türlerin işe koşulduğu da gözlenmektedir.

Tablo 9'da görüldüğü üzere, önerilen yazma etkinliklerinin öğrencinin günlük hayatta karşısına çıkabilecek yazılı anlatım türlerine ilişkin çalışmalar olduğu tespit edilmiştir. İngilizce ders kitabında metnin devamında yazılı anlatım etkinlikleri arasında ürün uyarısı, reklam ve gazete makalesi yazma gibi çalışmaların yer aldığı görülmektedir. Bu yazılı anlatım etkinliklerinde, altyazı, kitap etiketi ve öneri bildiren yazılar yazılması istenilmektedir. Ayrıca kitapta bu etkinliklerde nelere dikkat edileceğine dair açıklamalar da mevcuttur. Bu türler doğrudan günlük yaşamda bilgi alma, uyarılma, kültürel farkındalık için gerekli olan özelliğe sahiptir. Ders kitabının bu türlere yönelik metinler oluşturmayı içermesi, öğrenciyi gerçek yaşama hazırlamaya önem verilmesi ile açıklanabilir.

Ingilizce ders kitabında, yazılı anlatım çalışmaları geniş yer tutmaktadır. Kitapta yazılı anlatım etkinlikleri Wrting (Yazma), Projects (Projeler) ve Writing-Mini Lesson (Kısa Yazı Çalışmaları) başlıkları altında toplanmaktadır. Yazma etkinliklerinde, öğrenciye günlük ihtiyaçları doğrultusunda, daha önceki bilgi ve deneyimlerinden hareketle farklı konu ve türlerde metinler yazdırarak kendilerini ifade etme fırsatı sunulmaktadır.

Türkçe ders kitabında bulunan yazılı anlatım türleri, etkinlikler ve başvurulan yöntem ve teknikler Tablo 10'da gösterilmiştir: 
Tablo 10.

Türkçe Ders kitabındaki yazılı anlatım türleri, etkinlikler ve yöntem-teknikler

\begin{tabular}{|c|c|c|c|c|}
\hline Metin Adı & Türü & Yazma Etkinlikleri & Etkinliklerdeki Türler & $\begin{array}{l}\text { Yöntem ve } \\
\text { Teknikler }\end{array}$ \\
\hline Barış Manço & Biyografi & E-posta Yazma & Bilgilendirici Metin & Kontrollü Yazma \\
\hline Sol Ayağım & Hikâye & tobiyografi Yazma & Bilgilendirici Metin & Güdümlü Yazma \\
\hline $\begin{array}{l}\text { İnsanlarla } \\
\text { Geçinme Sanatı }\end{array}$ & Deneme & $\begin{array}{l}\text { Deneme } \\
\text { Yazma }\end{array}$ & Bilgilendirici Metin & Güdümlü Yazma \\
\hline $\begin{array}{l}\text { Naim } \\
\text { Süleymanoğlu } \\
\text { (Dinleme Metni) }\end{array}$ & Biyografi & $\begin{array}{l}\text { Röportaj } \\
\text { Yazma }\end{array}$ & Bilgilendirici Metin & $\begin{array}{c}\text { Kelime ve Kavram } \\
\text { Havuzundan } \\
\text { Seçerek Yazma }\end{array}$ \\
\hline $\begin{array}{l}\text { Üç Soru } \\
\text { (Serbest Okuma } \\
\text { Metni) }\end{array}$ & Masal & - & - & - \\
\hline
\end{tabular}

Türkçe ders kitabında bulunan metinler öyküleyici ve bilgilendirici olmak üzere 2 kısma ayrılmaktadır. Bu metinlere bağı etkinliklerde ise, sadece bilgilendirici metin türünde yazma çalışmalarına rastlanıımaktadır.

Tablo 10'a bakıldığında, yazma alanına yönelik her metinde sadece 1 etkinlik bulunmaktadır. Temadaki 4 metne bağıı etkinliklerin sadece bilgilendirici metin yazma çalışması içermesi de dikkat çekmektedir. Dolayısıyla temadaki metinlerle ilgili yazma alıştırmaları aynı türde yazılar içermektedir. Türkçe ders kitabındaki yazma etkinliklerinde kontrollü, güdümlü ve kelime havuzu tekniklerinin uygulandığı tespit edilmiştir. Serbest okuma metinlerinde ise yazılı anlatım çalışmaları bulunmamaktadır. İngilizce ders kitabında ise yazılı anlatım çalışması yapılmayan metin türü yoktur. Türkçe ders kitabında çoklu medya kaynakları kullanılarak e-posta yoluyla bilgilendirici bir metin yazılmasına yönelik etkinliklerin olduğu da tespit edilmiştir. Ders kitabındaki yazma etkinliklerinde elektronik ortamlardan yararlanılması günümüzde yaşam koşullarının önemsediğini göstermektedir. Ayrıca Türkçe ders kitabındaki yazma etkinliklerinde, İngilizce ders kitabıyla benzer yazma etkinlikleri mevcut olduğu görülmektedir. İncelenen temalardaki metinlerde, İngilizce ders kitabında 16 ve Türkçe ders kitabında 4 yazılı anlatım etkinliğinin olduğu tespit edilmiştir. Bu bulgulardan anlaşılacağı üzere, Ingilizce ders kitabında yazılı anlatım etkinlikleri daha fazladır. Bununla birlikte Ingilizce ders kitabındaki etkinliklerde farklı türlerde yazılı anlatım çalışması yapılmaktadır. Yine Türkçe kitabından farklı olarak yazılı anlatım etkinlikleri öğrenme alanına göre ayrı başlıklar altında verilmiştir. Türkçe kitabında ise, aynı türde 4 yazılı anlatım etkinliği yapılmaktadır. Deney raporu, şarkı sözleri, monolog, okuyucunun yorumları, yazara mektup, kütüphane araştırma raporu ve araştırma işlem basamakları gibi metin türleri Türkçe ders kitabında görülmemektedir. Ancak bu türlerin günlük hayatla doğrudan ilgili olması, dil öğretiminde kullanımını gerekli ve zorunlu kılmaktadır.

Ingilizce ders kitabı metin türleri, etkinlik çeşidi ve kullanılan yöntem ve teknikler ile Türkçe ders kitabından daha ayrıntılı ve çeşitlilik arz etmektedir. Bununla birlikte bu kitapta yazma çalışmalarının sürece dayalı (prewriting / yazma öncesi, drafting / yazma, revişing-publishing / gözden geçirme-yayınlama) ve üst düzey düşünme becerileri ile ilişkili yapılması da dikkat çekmektedir. Türkçe ders kitabında ise, yazılı anlatım çalışmalarında böyle bir durumun söz konusu olmadığı anlaşılmaktadır.

\section{Tartışma ve Sonuç}

Çocuklarda ana dili eğitimi dinleme ve konuşma yoluyla ailede başlar. Daha sonra çocuklar ilkokulla birlikte okuma ve yazma becerisi edinir. Dil becerilerinin sağlam temeller üzerine inşa edilmesinde ailede alınan eğitimle birlikte temel eğitim sürecinde yani ilkokul ve ortaokulda alınan eğitimin de büyük rolü bulunmaktadır. Okul çağında dil eğitimi, metinlerin ve alıştırmaların yer aldığı ders kitapları aracılığı ile şekillenir. Bu nedenle, dil eğitimi ders kitaplarının niteliği çok büyük önem taşır. Bu gerekçelerle, Amerika'da kullanılan İngilizce ders kitapları ile Türkiye'de kullanılan Türkçe ders 
kitaplarının, 7.sınıf örnekleminde, öğrenme alanlarına göre karşılaştırılmasını amaçlayan araştırmada şu sonuçlara ulaşılmıştır:

Türkçe ve İngilizce ders kitaplarının okuma öğrenme alanına yönelik özellikleri incelendiğinde; her ikisinde de hazırlık, söz varlığı ve anlama şeklinde bir bölümlendirmenin olduğu görülmektedir. Ingilizce ders kitabındaki okuma öncesi hazırlık çalışmaları 4 farklı başlıkta toplanmıştır. Tema ve metinle ilgili ön bilgi ve deneyimleri harekete geçirme amacı ile geçmişi anlama, odaklanma, metne yönelik bilgilendirici paragraf oluşturma gibi üst düzey düşünme içerikli hazırlık çalışmalarına yer verildiği belirlenmiştir. İngilizce ders kitabının hazırlık çalışmalarının oldukça ayrıntılı olduğu söylenebilir. Zira farklı konu alanları ile ilişki kurulması, görsellerle içeriğin somutlaştırılması gibi yönleri ile kitabın hazırlık çalışmalarının bilgiyi yapılandırma, çoklu zekâ ve öğrenci merkezli bir anlayışı yansıttığı değerlendirilebilmektedir.

Türkçe ders kitabındaki okuma öncesi hazırlık çalışmalarının Derse Hazırlık kısmında verilen sorulardan ibaret olduğu tespit edilmiştir. Hazırlık sorularının metinle ilgili ön bilgilerle ve günlük yaşamla ilişki kurmayı amaçladığı söylenebilir. Fakat öğrencilerin bu çalışmalarda nasıl bir yol izleyeceği, ulaştıklarını nasıl kaydedeceği ve ifade edeceği net değildir. Diğer taraftan öğrencilerin hazırlık çalışmalarındaki araştırma sonuçlarına dair yazılı bir rapor oluşturması beklenebilir. Belirli bir plana uymaksızın araştırma yapılması ve sonuçların gelişigüzel ifade edilmesi üst düzey becerileri geliştirmekten uzaktır. Tarih, güzel sanatlar, folklor gibi farklı disiplinlerle ilişki kurulmaksızın günlük yaşamla ilişkilendirmenin de yeterli olamayacağı da açıktır. Buna karşın İngilizce ders kitabının okuma öncesi hazırlık çalışmalarında sorudan ziyade düşünme becerilerine, farklı disiplinlerle ilişki kurmaya ve görsellerle desteklemeye önem verilmektedir. Bunlarla birlikte, gelecek derse hazırlık ile ilgili Türkçe ders kitabında ödev ve görevler verildiği, ancak İngilizce ders kitabında böyle bir bölümün olmadığı görülmektedir. Bu ihtiyacın diğer etkinliklerle karşılanabildiği anlaşılmaktadır.

Okuma stratejilerinin kullanımı açısından İngilizce ders kitabında her metne yönelik farkı stratejilerin (sözcük tanıma, yeniden okuma vb.) verildiği görülmektedir. Ayrıca kitapta metnin öncesinde ayrı bir başlık altında okuma stratejilerinin verilmesi, açıklanması ve gerektiğinde örnekler verilmesi dikkat çekmektedir. Bununla birlikte metnin kenarlarında okuma esnasında yararlanılacak stratejiler de verilerek metnin daha iyi anlaşılması hedeflenmektedir.

Türkçe ders kitabında ise sadece metin öncesinde stratejiler verilmektedir. İncelenen temada da, Türkçe Dersi Öğretim Programı'ndaki (2018) stratejilerden sesli okuma ve empatik okuma önerilmiştir. Serbest okuma metinleri için aynı durum geçerli değildir. Topuzkanamış (2010) da ilgili çalışmasında okuma stratejilerinin ders kitaplarında yeterli düzeyde yer almadığını ortaya koymaktadır. Buna karşın okuma stratejileri okuduğunu anlama sürecinde oldukça etkilidir (Kırmızı, 2008; Özyılmaz ve Alçı, 2011). Öğrencilere hangi okuma stratejileri ile okumanın yapılacağının ve bu stratejilerin nasıl uygulanacağının öğretilmesi gerekmektedir (Berkowitz, 1986; Paris ve Jacobs, 1984; Vaughan ve Estes, 1986).

Söz varlığına ilişkin İngilizce ders kitabında Kelime Hazinesi Oluşturma başlı̆ı altında etkinlikler yapıldığı belirlenmiştir. Kitapta söz varlığı çalışmaları metin öncesinde, metnin kenarlarında ve sonrasında ayrı ayrı yapılmaktadır. Türkçe ders kitabında ise söz varlığı çalışmaları metinden sonra bulunmaktadır. İngilizce ders kitabında Sözcük Bankası-Anahtar Kelime, Önekler-Kelime Türetme ve Heceleme Stratejisi gibi etkinliklerle sözcük öğretimi gerçekleşmektedir. Türkçe kitabında ise, Anlamı Bilinmeyen Kelimeyi Bulma, Tahmin Etme, Atasözü-Deyim ve Özdeyiş Bulma Çalışmaları, Bağlamdan Hareketle Anlamı Bilinmeyen Kelimeleri Bulma gibi etkinliklerle sözcük öğretimi yapılmaktadır.

Türkçe ders kitabında sözcük türleri gibi dil bilgisine yönelik çalışmalar, okuma öğrenme alanı içinde verilmektedir. Ancak İngilizce ders kitabında, dil bilgisine yönelik etkinlikler söz varlı̆ı çalışmalarının dışında Dil Bilgisi Becerileri Oluşturma-Uygulama başlığı altında ayrı biçimde verilmektedir. Mert (2013) de çalışmasında, Türkçe dersi çalışma kitaplarında kullanılan sözcük öğretimine yönelik etkinliklerin sayılarının yeterli olmadığı sonucuna varmıştır. Aynı şekilde Karadağ ve Kurudayıoğlu (2010: 435) ise çalışmasında, Türkçe ders kitapları ile öğrencilerin kelime hazinelerinin ortaklık düzeyinin düşük olduğunu, bunun da öğrenciye görelik açısından belirli bir ölçütten uzak hareket edildiğini gösterdiğini ifade etmektedir. Baysal (2007) da incelemiş olduğu 7.sınıf Türkçe ders kitabının söz varlığı açısından zayıf bir nitelik gösterdiğini öğretilmek istenen yeni terimler kısa 
tanımlarla ve az örneklerle tarif edildiğini belirtmektedir. Yine söz varlığına yönelik Türkçe ders kitaplarını inceleyen benzer çalışmalara bakıldığında, ders kitabındaki etkinliklerin ve metinlerin söz varlığını geliştirmede yetersiz olduğu tespit edilmiştir (Aslan, 2013; Başdamar, 2010; Büyükhellaç, 2014; Doğan, 2016; Güzel, 2015; Maden ve diğ., 2017).

Metni anlama çalışmaları açısından İngilizce ders kitabında, sayfa kenarlarında Metne Odaklanma ile Metin ve Yaşamınız başlıkları ile anahtar kelimeler verilmektedir. Yine metin kenarlarında Eleştirel Bakış başlığı ile metne yönelik sorular da bulunmaktadır. Metinden sonra ise Anladıklarınızın Kontrolü şeklinde soruların verildiği görülmektedir. Anahtar kelimelerin ve anlamaya yönelik soruların ana fikri, mesajı belirlemeye ve öğrencinin yaşamla metin arasında ilişki kurmasına yönelik olduğu da dikkat çekmektedir. Ayrıca eleştirel bakış şeklinde, değerlendirme ve çıkarım yapmanın önemli görülmesi düşünme becerilerini harekete geçirmektedir. Zira tüm kitapta metinlerin uygun kısımlarında sırasıyla şaşırtıcı fikir, ilişki kurma, sonuç çıkarma, değerlendirme ile karşılaştırma ve çelişki oluşturma gibi düşünme becerilerinin verilmesi bu konunun ne kadar önemli görüldüğünün kanıtıdır. Kitapta metinle ilgili çalışmalardan sonra Metinden Anladıklarınız gibi bir değerlendirme bölümünde soruların yöneltildiği de görülmektedir.

Türkçe ders kitabında metin bittikten sonra metni anlamaya yönelik 2 ayrı etkinlik bulunmaktadır. Bu etkinliklerden birincisinde metni anlamaya yönelik sorular, ikincisinde ise konu ve ana fikri buldurma amaçlanmaktadır.

İngilizce ve Türkçe ders kitaplarında metni anlama kısmında öğrencilere soru yöneltildiği anlaşıımaktadır. Ancak İngilizce kitabında okuma esnasında da düşünme becerileri ile ilişkilendirilmiş anlamaya yönelik sorular mevcuttur. Türkçe ders kitabında bu şekilde okuma esnasında öğrencilere sunulan soru bulunmamaktadır. Geçmiş Türkçe ders kitaplarında bu tür sorular kullanılmakta iken, 2018 yılında yenilenen kitaplarda bundan vazgeçilmiştir. Fakat "metin okunurken sorulan sorular metinle iletişimi sağlar, öğrencilere dikkat çeken hususla hakkında ipucu verir ve daha çok düşünmeyi sağlar" (Lienemann ve Reid, 2006: 153). Temizkan (2009) da bu doğrultuda, okuma için en önemli unsurun metni anlamak olduğunu ifade etmiştir. Dolayısıyla Türkçe 7.sınıf ders kitabında bilgi ağılıklı değil üst düzey düşünme becerileri kapsayan sorular sorulmalıdır. Benzer şekilde, Razgatlıoğlu (2010) incelediği 5.sınıf Türkçe ders kitabında üst düzey düşünme becerilerini harekete geçiren yeterince unsurun olmadığını belirtmiştir. Yıldız, Ceran ve Toksun (2011) araştırmasında, ders kitaplarındaki düşünme becerilerine (eleştirel düşünme, yaratıcı düşünme, iletişim kurma vb.) yönelik unsurlarla ilgili öğretmenlerin çoğunlukla kısmen ya da hayır düzeyinde görüş belirttiğini ortaya koymuşlardır.

Ingilizce ders kitabında konuşma ve dinleme çalışmaları birlikte ele alınmakta ve metinden sonra birtakım etkinlikler aracılı̆ııla bu beceriler geliştirilmektedir. Etkinlikler konuşma becerisi ağılıklıdır, ayrıca bu alana yönelik etkinlikler günlük yaşamdan kesitlerle yapılandırılmıştır. İngilizce ders kitabındaki konuşma ve dinleme etkinliklerinin tarih, müzik, medya gibi günlük yaşamla ilişkili alanları içerdiği de görülmüştür. Bunlarla birlikte, konuşma ve dinleme etkinlikleri için internet kaynaklarına bağlantılar verilmiştir. Öğrencilerin bu becerilerle ilgili uygulamaları internet kaynakları üzerinde gerçekleştirmeleri ve böylece temaya dair içeriği kavramaları hedeflenmektedir. İngilizce ders kitabının elektronik kaynaklar üzerinde örnek kullanımları öğrencilere sunmasının, teknoloji ve medyayı öğretim sürecine yerleştirmiş olduğunu ve bu açıdan çağın gereksinimlerine cevap verdiğini söylemek doğru olacaktır. Öğrencinin konuşma ve dinleme becerilerini geliştirmeleri için proje konuları sunulmaktadır. Bu projeler içinde televizyon gibi araçların kullanılması da öğrencilerin izleme yeteneklerini devreye sokmaktadır. İngilizce ders kitabında, konuşma ve dinleme alanı için hikâye, şiir ve bilgilendirici metin türlerini içeren etkinlikler bulunmaktadır. Yine kitapta telefonla karşılıklı konuşma, monolog, konferans, sözlü tarih gibi sözlü anlatım türlerinin olması; rol oynama, iş birlikli öğrenme, tartışma, serbest konuşma, ikna edici konuşma, yaratıcı konuşma ve empati kurma tekniklerin kullanılması dikkat çekmektedir. Konuşma türleri ve kullanılan tekniklerin gerçek bağlamda becerilerin öğretimine yönelik olduğu söylenebilir. Dolayısıyla İngilizce ders kitabı bu özellikleri ile konuşma ve dinleme öğretimi için elverişli ortamlar sunmaktadır. Kalaycı ve Durukan'nın (2019) yabancı dil olarak Türkçe ve İngilizce ders kitaplarını karşılaştırdığı çalışmasında da konuşma ve dinleme etkinlikleri açısından İngilizce ders kitaplarının daha fazla içerik barındığı ortaya konulmuştur. 
Türkçe ders kitabında hikâye, deneme, biyografi ve masal türlerinde metinler bulunmaktadır. Ancak kitapta bu metinlerin öncesinde veya sonrasında dinleme veya konuşma etkinliği bulunmamaktadır. Biyografi türünde bir dinleme metninin kitapta yer aldığı, ancak bu metin için de kitapta dinlemeye yönelik herhangi bir etkinliğin olmadığı belirlenmiştir. Bu bulgu, Türkçe ders kitabında konuşma ve dinlemeye yönelik öğrenme-öğretme çalışmalarının öğretmen tercihine bırakıldığına yorulabilir. Buna karşın İngilizce ders kitabında bu alana yönelik etkinlikler, kullanılacak yöntem ve teknikler ayrıntılarıyla açıklanmıştır. İngilizce kitabının 2000 yılında basılması göz önüne alındığında, elektronik kaynak kullanımı için linkler verilmesi önemli bir özellik olarak değerlendirilebilir. Türkçe ders kitabı ise, 2018 yılında basılmış olmasına rağmen elektronik kaynak kullanımı, sadece dinleme/izleme metinlerinin dinletilmesi ve blog gibi bazı metin örnekleri sınırlı kalmaktadır. Hâlbuki Türkiye'de de öğrencilerin kullanabileceği ve faydalı olabilecek birçok elektronik kaynak mevcuttur. Özellikle 2012 yılında hayata geçirilen Fırsatları Artırma ve Teknolojiyi İyileştirme Hareketi (FATiH) ile bir bilgi paylaşım platformu olan Eğitim Bilişim Ağı (EBA) kurulmuştur. EBA ile her öğrenci platformda bulunan eğitim materyallerinden ücretsiz faydalanabilmektedir. EBA sadece konuşma ve dinleme alanı için değil, tüm öğrenme alanlarına yönelik materyaller içermektedir. Fakat bu imkandan yararlanılması için ders kitabında bir bağlantının sağlanamamış olması bir eksiklik olarak değerlendirilmektedir. Maden ve Önal (2020) da ilgili araştırmasında EBA'daki içeriklerin ders kitapları ve programla yeterince uyumlu olmadığını belirtmiştir. Uçgun (2007) konuşma becerisinin geliştirilebilmesi için öğrencilere ders saatinde veya ders dışı zamanlarda bazı eğitsel oyunlar oynatılması gerektiğini belirtmiştir. Maden (2017) de, drama ve rol oynama tekniklerinin sözlü ve sözsüz iletişimi üst seviyede geliştirdiğini belirtmiştir. Buna rağmen 7. sınıf Türkçe ders kitabında drama uygulamalarının bulunmadığı, bu nedenle konuşma ve dinleme becerilerini geliştirme sürecinde canlandırma ve alıştırma imkânı sunan yöntem ve tekniklerden yeterince yararlanılmadığı görülmektedir.

Yazma öğrenme alanı açısından ders kitapları değerlendirildiğinde; İngilizce ders kitabında deney raporları, şarkı sözleri, monolog, okuyucunun yazılanlarla ilgili yorumları, yazara mektup, kütüphane araştırma raporu ve araştırmanın işlem basamakları gibi 7 farklı metin türünde etkinliğin bulunduğu tespit edilmiştir. Bu türler Türkçe ders kitabında bulunmamaktadır. Ingilizce ders kitabındaki yazma çalışmalarının öğrencilerin günlük ihtiyaçlarını esas aldığı söylenebilir. Metin türleri içinde elektronik metinler olmazsa da elektronik kaynaklarla ilişkili etkinlikler oldukça fazladır. İngilizce ders kitabının genel olarak yazılı anlatım etkinlikleri bakımından zengin ve çeşitlilik arz ettiği belirlenmiştir. Yazma etkinliklerinin okuma metni olarak sunulan metin türünün dışındaki türlere yönelik metin çalışmaları içermesi de önemlidir. Örneğin, öyküleyici bir metin işlenirken etkinliklerde bilgilendirici ve ikna edici yazma çalışmaları yapılabilmektedir. İngilizce ders kitabında yazma çalışmalarında iş birlikli ögrenme, metin tamamlama, boşluk doldurma, kontrollü, güdümlü, kelime havuzu ve yaratıcı yazma tekniklerinin uygulandığı tespit edilmiştir. Yine kitabın yazma çalışmalarında inşa, fikir bankası ve proje gibi başlıklar altında mektup, kısa gezi yazısı, psikayatri raporu yazma, ürün uyarısı, reklam, gazete makalesi, altyazı, kitap etiketi ve öneri bildiren yazılar yazma gibi uygulamalar yapılmaktadır. İngilizce ders kitabının metin türü bakımından günlük ihtiyaçlara göre çeşitlenen örnekler içerdiği ve etkinlik bakımından da en yoğun öğrenme alanının yazma olduğu belirlenmiştir. İngilizce ders kitabında yazma çalışmalarının sürece dayalı (yazma öncesi, yazma, gözden geçirmeyayınlama) ve üst düzey düşünme becerileri ile ilişkili biçimde yapılandırılmıştır. Süreç temelli yazma yaklaşımı Türkçe Dersi Öğretim Programı'nda (2018) da bulunmaktadır. Ancak Türkçe ders kitabındaki etkinliklere bu durum tam olarak yansıtılamamıştır.

Türkçe ders kitabında ise, bilgilendirici, hikâye edici ve şiir türünde metinler yer almaktadır. Bununla birlikte kitapta e-posta ve sosyal medya mesajları gibi elektronik ortamda kullanılabilecek metin türlerinin olması da dikkat çekmektedir. Bu açıdan ders kitabının Türkçe Dersi Öğretim Programının (2018) metin türlerine yönelik belirlediği ilkelere uygun olduğu söylenebilir. Türkçe ders kitabındaki metinlere bağlı etkinliklerde, sadece bilgilendirici metin türünde yazma çalışmalarına rastlanılmaktadır. Yazma alanı ile ilgili her metinde bir etkinlik bulunmaktadır. Dülger (2011) de Türkçe ders kitaplarında yazılı anlatım becerilerini davranışa dönüştürecek etkinliklerin bulunması gerektiğini ifade etmiştir. Bu hâliyle yazma alanına yönelik etkinliklerin sınırlı olduğu söylenebilir. Karagöl ve 
Tarakçı (2018: 99) da Türkçe ders kitaplarında yazma kazanımları ile etkinlikler arasındaki uyumun yeterli olmadığını ifade etmektedir. Türkçe ders kitabındaki yazma etkinliklerinde kontrollü, güdümlü ve kelime havuzu tekniklerine başvurulduğu belirlenmiştir. Yazma etkinliklerinde e-posta yazma gibi elektronik ortamlardan yararlanılması, yaşam koşullarının önemsediğinin işaretidir. Bunun yanında otobiyografi, röportaj ve form doldurmaya dayanan etkinlikler de mevcuttur. Alanyazında Coşkun ve Narinç'in (2018) incelediği 5. sınıf Türkçe ders kitabında, bazı kazanımlara ve yöntem-tekniklere fazlasıyla ağılık verildiği, bazılarının ise ihmal edildiği tespit edilmiştir. Özçakmak (2011) da çalışmasında, ders kitaplarında programa uygun ve amaca hizmet eden yazılı anlatım çalışmalarııın olması gerektiğine yönelik öğretmen görüşünün fazla olduğu ifade etmiştir. Aynı şekilde Özkara (2006) ders kitaplarındaki yazmaya yönelik kazanımların dağıımının düzgün olmadığı sonucuna varmıştır. Bu sonuçlar, araştırmada ulaşılan sonuçları desteklemektedir. Bunlara ek olarak, yabancı ders kitapları ile Türkçe ders kitaplarını karşılaştıran çalışmalar sonuçlar ile de ulaşılan sonuçlar örtüşmektedir. Karakuş ve Turgut (2017) yaptıkları çalışmada Avusturalya'da okutulan ders kitaplarının daha işlevsel ve çocukların sosyal yaşama hazırlanmasında etkin bir içeriğe sahip olduğu Türkiye'de okutulanların ise bu işlevsellikten uzak olduğu sonucuna varılmıştır. Şimşek (2015) ise yaptığı çalışmada, Amerika'da okutulan ders kitaplarının tür açısından Türkiye'de okutulan kitaplarından daha zengin olduğunu tespit etmiştir.

Sonuç olarak, İngilizce ders kitabının okuma öncesi hazırlık çalışmalarının ön bilgi ve deneyimleri harekete geçirme, yaşamla ilişkilendirme ve düşünme becerilerini kullandırma yönleri ile Türkçe ders kitabından farklılaştığı belirlenmiştir. Okuma stratejileri bakımından her iki kitapta da planlama olduğu, ancak İngilizce kitabının daha ayrıntılı hazırlandığı, rehberlik yönünün güçlü olduğu görülmüştür. Söz varlığını zenginleştirme konusunda ise, İngilizce ders kitabında metin öncesi, metin sırası ve metin sonrası; Türkçe ders kitabında ise sadece metinden sonra etkinliklerin bulunması dikkat çekmektedir. Türkçe kitabında metin öncesinde veya sonrasında dinleme veya konuşma etkinliğine yer verilmemişken İngilizce ders kitabında etkinlikler, kullanılacak yönteme dair açıklamalar ve elektronik kaynak bağlantılarıyla sunulmuştur. Her iki kitapta da metni anlama çalışmalarında sorulara başvurulduğu ancak İngilizce ders kitabında anlama etkinliklerinde üst düzey düşünme basamaklarına göre bir yapılandırmanın olduğu tespit edilmiş̧ir. İngilizce ders kitabının yazııı anlatım türü, etkinlik çeşidi ve kullanılan yöntem ve teknikler bakımından Türkçe ders kitabından daha ayrıntılı ve çeşitlilik arz ettiği ulaşılan önemli sonuçlar arasındadır.

\section{Öneriler}

Bu sonuçlardan hareketle, Türkçe ders kitapları ile ilgili aşağıdaki önerilerde bulunulabilir:

Türkçe ders kitaplarında üst düzey düşünme becerilerini geliştirecek metin ve etkinliklere yer verilebilir. Bunun için ders kitaplarında bilgilendirici, hikâye edici ve şiir türünde metinlerle birlikte internet bağlantılı (linkli), talimat, kılavuz ve yönergeli metinlere; alıntı ve kısaltmalara, grafik, harita ve çizelgelere; karikatürlere, gazete ve dergi metinlerine; ilan, reklam, broşürlere; form ve faturalara yer verilmesi üstü düşünme becerilerini desteklemekte fayda sağlayabilir.

Öğrencilerin okuduğunu anlama becerisini geliştirmek için ders kitabında okuma stratejilerine ağılık verilebilir. Okuma stratejilerinin nasıl kullanılacağına dair açıklamalar sayfa kenarlarına eklenebilir.

Dinleme ve konuşmaya yönelik etkinliklerde psikomotor becerileri geliştirecek drama ve rol oynama gibi yöntem ve tekniklere başvurulabilir.

Yazma becerilerini geliştirmek için ders kitaplarında alıştırma içeren etkinlikler artırılabilir ve bu etkinlikler yöntem ve teknik açısından zenginleştirilebilir.

Ders kitaplarındaki etkinlikler için öğrencilere rehber olabilecek açıklamalar verilebilir.

Ders kitaplarında elektronik kaynak (internet sayfaları, e-sözlükler, videolar vb.) kullanımına ağırlık verilebilir. 


\section{Kaynaklar}

Aslan, T. (2013). 7. Sını öğrencilerinin Türkçe ders kitaplarındaki anlamını bilmedikleri kelimelerden hareketle söz varlığını geliştirmelerine yönelik bir araştırma. Yayımlanmamış yüksek lisans tezi. Ankara: Gazi Üniversitesi Eğitim Bilimleri Enstitüsü.

Arhan, S. ve Gültekin, i. (2015). Türkçe dersi ilköğretim programlarında benimsenen tematik yaklaşımın metin seçimine etkileri yönünden değerlendirilmesi. Milli Eğitim Dergisi, 43 (199), 5-31.

Aytan, T., Çalıcı, M. ve Erdem, A. (2018). Türkçe ders kitaplarındaki öyküleyici metin kahramanlarının rol model olma durumları üzerine bir araştırma. Uluslararası Bilimsel Araştırmalar Dergisi (IBAD), 3 (2), 634-652.

Başdamar, G. (2010). Yazılı çalışmalar yaptırılarak öğrencilerin sözcük dağarcı̆̆ını zenginleştirme uygulamaları, etkinlikleri ve ölçme değerlendirmeleri. Yayımlanmamış yüksek lisans tezi. Erzincan: Erzincan Üniversitesi Sosyal Bilimler Enstitüsü.

Beaugrande, R. \& Dressler, W.U. (1981). Introduction to text linguistics. London: Longman.

Borkowski, J. G., Reid, M. K., \& Kurtz, B. E. (1984). Metacognition and retardation: Pragmatic, theoretical, and applied perspectives. In P. H. Brooks, R. Sperber \& C. McCauley (Eds.), Learning and cognition in the menfully retarded (p. 55-75). Hillsdale. NJ: Erlbaum.

Boy, M. (2006). 5. sınıf Türkçe ders kitaplarındaki etkinliklerin öğrenme ve öğretme kuramları açısından değerlendirilmesi. Yayımlanmamış yüksek lisans Tezi. Ankara: Ankara Üniversitesi Sosyal Bilimler Enstitüsü.

Büyükhellaç, S. (2014). Ortaokul Türkçe ders kitaplarındaki söz varlığının incelenmesi. Yayımlanmamış yüksek lisans tezi. Trabzon: Karadeniz Teknik Üniversitesi Eğitim Bilimleri Enstitüsü.

Coşkun, H. ve Narinç, F. N. (2018). 2017 Türkçe öğretim programı esas alınarak hazırlanan 5. sınıf Türkçe ders kitabında yer alan yazma ve konuşma etkinliklerinin incelenmesi. Iğdır University Journal of Social Sciences 16, 627-645.

Coşkun, E. ve Taş, S. (2008). Ders kitaplarına metin seçimi açısından Türkçe öğretim programlarının değerlendirilmesi/Evaluation of Turkish curriculums in terms of text selection for textbooks. Mustafa Kemal Üniversitesi Sosyal Bilimler Enstitüsü Dergisi, 5 (10), 59-74.

Demirel, Ö. (2007). Öğretimde planlama ve değerlendirme, öğretme sanatı. Ankara: PegemA Yayıncılık

Demirbaş, H. (2006). Sosyal bilimler öğretiminde tematik yaklaşım, bilim ve aklın aydınlığında. Ankara: Millî Eğitim Yayınları.

Doğan, F. (2016). Türkçe dersi ortaokul öğrenci çalışma kitaplarındaki etkinliklerin söz varlığı üzerine bir araştırma. Yayımlanmamış yüksek lisans tezi. Siirt: Siirt Üniversitesi Sosyal Bilimler Enstitüsü.

Dülger, M. (2011). Konuşma becerisinin ilköğretim öğrencilerine öğretimi üzerine bir inceleme. Yayımlanmamış yüksek lisans tezi. İzmir: Dokuz Eylül Üniversitesi Eğitim Bilimleri Enstitüsü.

Göçer, A. (2010). illköğretim Türkçe Ders Kitaplarının Ölçme ve Değerlendirme Açısından İncelenmesi. Atatürk Üniversitesi Sosyal Bilimler Enstitüsü Dergisi, 11 (1), 197-210.

Güleç, İ. ve Demirtaş, T. (2013). İlköğretim 8. sınıf ana dili ders kitapları üzerine karşılaştırmalı bir çalışma: Türkiye-Amerika Birleşik Devletleri örneği. Sakarya Üniversitesi Eğitim Bilimleri Enstitüsü Dergisi, 2 (1), 74-91.

Güzel, G. (2015). Ortaokul Türkçe ders kitaplarında sözcük öğretiminin yaratıcı dil öğretimi açısından değerlendirilmesi. Yayımlanmamış yüksek lisans tezi. Ankara: Başkent Üniversitesi Eğitim Bilimleri Enstitüsü.

Gün, M. (2013). Ilköğretim ikinci kademe Türkçe dersi okuma etkinliklerinde öğrenme ortamları ile kullanılan araç-gereçlerin yeterliliği. Tarih Okulu Dergisi, 6 (15), 545-567.

Kalaycı, D. ve Durukan, E. (2019). Yabancı dil olarak Türkçe ve İngilizce öğretimi ders kitaplarının öğrenme alanları bakımından karşılaştırılması. Uluslararası Türkçe Edebiyat Kültür Eğitim Dergisi, $8(4), 2162-2177$.

Karadağ, Ö. ve Kurudayioğlu, M. (2010). 2005 Türkçe programına göre hazırlanmış ilköğretim birinci kademe Türkçe ders kitaplarının kelime hazinesi. Türklük Bilimi Araştırmaları, 27, 423-436.

Karagöl, E. ve Tarakçı, R. (2018). Yazma becerisi kazanımları açısından ortaokul Türkçe ders kitapları. International Journal of Languages' Education and Teaching, 6 (4), 87-100. 
Karakuş, N. ve Turgut, E. (2017). Avustralya'daki ve Türkiye'deki 8. sınıf ana dili ders kitaplarında yer alan metinlerin tema ve tür bakımından karşılaştırılması: Cambridge ve MEB Örneği. International Journal of Languages' Education and Teaching, 5 (3), 632-650.

Kırmıı S. F. (2008). Türkçe öğretiminde yaratıcı drama ve yönteminin tutum ve okuduğunu anlama stratejileri üzerindeki etkisi. Pamukkale Üniversitesi Eğitim Fakültesi Dergisi, 23 (1), 95-109.

Kırkkılıç, A. ve Maden, S. (2010). İlköğretim ve lisans programlarındaki değişiklikler sonrasında Türkçe öğretmenliği mesleğinin ve Türkçe eğitimi bölümlerinin durumu. Türklük Bilimi Araştırmaları, 27, 477-502.

Kurt, B. (2018). Ana dili eğitiminde kullanılan ders kitapları üzerine bir karşılaştırma: Türkiye ve Macaristan örneği. Anadolu 1. Uluslararası Multidisipliner Çalışmalar Kongresi, 28-29 Aralık 2018, (s. 1170-1181). Diyarbakır.

Lienemann, T. ve Reid, R. O. (2006). Strategy instruction for students with learning disabilities. New York: The Guilford Press.

Maden, S. (2017). Drama ile dil öğretimi. Ankara: Nobel Bilimsel Eserler.

Maden, S. ve Önal, A. (2020). Eğitim bilişim ağı (eba) içerik modülündeki Türkçe dersi ile ilgili dokümanlar. Eğitim Teknolojisi Kuram ve Uygulama, 10 (1), 25-50.

Mert, E. L. (2013). Illköğretim Türkçe programı ile Türkçe çalışma kitaplarındaki kazanım ve etkinliklerin sözcük öğretimi açısından değerlendirilmesi. Dil ve Edebiyat Eğitimi Dergisi, 2 (5), 13-31.

Melanlıoğlu, D., Çiftçi, Ö. ve Çeçen, M.A. (2014). Altıncı sınıf Türkçe ders kitaplarındaki metinlerin okunabilirlik açısından değerlendirilmesi. Elektronik Sosyal Bilimler Dergisi, 6 (22), 206-219.

Millî Eğitim Bakanlığı (2018). Ortaokul ve imam hatip ortaokulu 7. sınıf Türkçe ders kitabı. Ankara: Millî Eğitim.

Millî Eğitim Bakanlığı (2018). İlköğretim Türkçe dersi $(5,6,7$, 8. sınıflar) öğretim programı. Ankara: Millî Eğitim.

Millî Eğitim Bakanlığı (2006). İlköğretim Türkçe dersi $(6,7$, 8. sınıflar) öğretim programı. Ankara: Millî Eğitim.

Özçakmak, M. (2011). Illköğretim 6-8. sınıf Türkçe ders kitaplarındaki yazma becerisi ile ilgili etkinliklerin ögrretmen görüşlerine göre değerlendirilmesi. Yayımlanmamış yüksek lisans tezi. Hatay: Mustafa Kemal Üniversitesi Sosyal Bilimler Enstitüsü.

Özkara, Y. (2006). Türkçe dersi öğrenci çalışma kitaplarının Türkçe programında geçen yazma kazanımlarını karşılama durumu, Ulusal Sınıf Öğretmenliği Kongresi Kitabı C.1 (s.38 - 47).

Özyılmaz, G. ve Alcı, B. (2011). Illköğretim 7. sınıf öğrencilerine okuduğunu anlama stratejilerinin öğretiminin okuduğunu anlama başarısı üzerine etkisi. Kuramsal Eğitimbilim Dergisi, 4 (1), 7194.

Prentice Hall (2000). Prentice hall litrature bronze level. NewJersey, USA: Pearson Education Inc.

Paris, S. G. \& Jacobs, J. E. (1984). The benefits of informed instruction for children's reading awareness and comprehension skills. Child Development, 55, 2083-2093.

Sezgin, G. (2000). ilköğretim okullarının altıncı sınıfları için yazılan Türkçe ders kitapları üzerine bir inceleme. Yayınlanmamış yüksek lisans tezi. Ankara: Gazi Üniversitesi Sosyal Bilimler Enstitüsü.

Şahin, A. (2008). illköğretim birinci sınıf Türkçe ders kitabı, öğrenci çalışma kitabı ve öğretmen kılavuz kitabının öğretmen görüşlerine dayalı olarak değerlendirilmesi. Ahi Evran Üniversitesi Kırşehir Eğitim Fakültesi Dergisi (KEFAD), 9 (3), 133-146.

Şimşek, N.D. (2015). Amerika'daki 8. sınıf İngilizce ve Türkiye'deki 8. sınıf Türkçe ana dili ders kitaplarında yer alan metinlerin tema/ünite ve türleri açısından karşılaştırılması. International Journal of Social Sciences and Education Research, 1 (4), 1314-1326.

Temizkan, M. (2009). Metin türlerine göre okuma eğitimi. Ankara: Nobel Yayın Dağıtım.

Topuzkanamış, E. (2010). Türkçe ders kitaplarında okuma stratejileri. 10. Uluslararası Dil, Yazın ve Deyişbilim Sempozyumu 3-4-5 Kasım 2010. Gazi Üniversitesi, Ankara.

Tutsak, S. ve Batur, Z. (2011). Cumhuriyetten günümüze Türk eğitim sisteminde ders kitabı: iki örneğin karşılaştırılması. Turkish Studies, 6 (3), 355-389.

Tüm, G. (2016). 5. ve 6. sınıf ilköğretim Türkçe ders kitaplarında yer alan metin önü ve sonu sorularının Bloom Taksonomisi'ne göre değerlendirilmesi. Turkish Studies, 11 (14), 731-748. 
Uçgun, D. (2007). Konuşma eğitimini etkileyen faktörler. Erciyes Üniversitesi Sosyal Bilimler Enstitüsü Dergisi, 1 (22), 59-67.

Ülper, H. ve Yalınkılıç, K. (2010). Son iki Türkçe programına göre hazırlanan Türkçe ders kitaplarındaki metin sonu sorularının nicel ve nitel görünümü. Uluslararası Sosyal Araştırmalar Dergisi, 3 (12), 449-461.

Vaughan, J.L. \& Estes, T.H. (1986). Reading and reasoning beyond the primary grades. Newton, MA: Allyn and Bacon.

Yıldız, D., Ceran, D. ve Erdağı Toksun, S. (2011). Türkçe ders kitaplarındaki metinlerin öğretmen görüşlerine göre değerlendirilmesi. I. Uluslararası Türkçe Eğitimi Sempozyumu, 15-17 Aralık 2011 (ss. 123-130). Ankara.

Yurt, G. ve Arslan, M. (2014). 7. Sınıf Türkçe ders kitaplarının şekil-içerik-metin yönünden incelenmesi: zambak ve pasifik yayınları örneği. Süleyman Demirel Üniversitesi Fen-Edebiyat Fakültesi Sosyal Bilimler Dergisi, 31, 317-327.

\section{Introduction}

\section{Extended Abstract}

Textbooks are the basic materials of language teaching. This applies to both mother tongue and foreign language teaching. It is important that textbooks are prepared according to the characteristics of language skills and the needs of the students. Therefore, the type, order, visuals and text size of the texts in the textbook should be according to the student level. Vocabulary should also be structured according to the level of the student. Activities and text content should be supported. Activities for language skills should include different strategies and methods. To achieve this, they must be continuously developed. In the development of textbooks, it is useful to compare textbooks prepared for different languages. It has been observed that there are researches comparing the textbooks in the literature according to their learning areas. In this study, Turkish and English textbooks will be compared in terms of improving language skills, compliance with contemporary approaches and relative to student level. Thus, it is envisaged to present guiding findings to those who prepare textbooks.

\section{Method}

In the research, it is aimed to compare the Turkish textbooks in secondary schools and the English textbooks used in mother tongue teaching in America according to their learning areas. For this purpose, qualitative research approach has been adopted in the study. Document review technique has been used in data collection stage. In the study, the data have been collected under the title of learning areas and the textbooks are compared in this direction. The data source of the study is composed of the 7th grade Turkish textbook of the secondary school published by the Ministry of National Education and the Prentice Hall Literature Bronze Level which is used at the 7th grade level in the USA.

\section{Result and Discussion}

As a result of the study, it has been determined that the English textbook differs from the Turkish textbook in terms of using pre-knowledge and experiences, associating with life and using thinking skills in the preparatory works of the reading learning area. In terms of reading strategies, it is determined that there are strategies in both books, but strategies are given in more detail in English textbook and guidance is given for teaching these strategies. In the vocabulary part, it has been seen that importance given to enrich the vocabulary in both books. In the English textbook, pre-text, text order and post-text activities and vocabulary have been included. In the Turkish book, only word works have been found in the activities section after the text. In the Turkish book, the topics related to grammar are also included in the activities. This is not the case in the English textbook. Grammar subjects have been written and given under separate titles. Text pre-text, text order and post-text in the English textbook about the text comprehension; In the Turkish textbook, only the activities after the text are among the results. In addition, it is found that questions that found in both books to 
understand the text, but in the English textbook, comprehension activities have been planned by considering the high-level thinking steps. In the English book, it has been determined that techniques such as conversation, monologue, conference, oral history are used as well as techniques such as role playing, collaborative learning, discussion, free speech, convincing speech, creative speech and empathy. In the Turkish textbook, it is determined that there is no activity, method and technique in the theme examined for these areas. In the field of writing learning, the book is given under different titles according to the learning area. In the Turkish book, it has been found that only informative text types were found in the activities, and in the English textbook there were different types of writing activities. It was determined that the text types such as the experimental report, lyrics, monologue, reader's comments, letter to the author, library research report and research steps were not included in the Turkish textbook. It is concluded that the Turkish textbook is very weak in terms of the use of electronic resources and is limited to the listening / watching texts. In the English textbook, it is concluded that the electronic resources for the learning areas are quite rich. In the context of this study, it is necessary to base the high-level thinking skills in Turkish textbooks and enrich the activities, methods and techniques in the learning areas and prepare the textbooks that will enable the student to structure the information in their minds. 